\title{
Othering Muslims? A Content Analysis of the Spanish Press Coverage ${ }^{1}$
}

\author{
By Rafael Durán*
}

\begin{abstract}
By conducting a media frame analysis, the aim of this paper is to know whether and to what extent the Spanish large-circulation quality newspapers 'Abc,' 'El Pais' and 'La Vanguardia' portray Muslims and Islam as a strange, monolithic and problematic 'other'. Variations according to ideology and the nature of the events reported are observed. This is an empirical and longitudinal content analysis examining the full coverage (432 texts, once news related to terrorism were excluded) throughout an entire year (2017). Insofar as the media shape public opinion, to analyse media symbolic construction of Muslims and Islam as included/excluded, diverse/monolithic, and friendly/threatening may be helpful in trying to explain perceptions and attitudes toward them. Findings demonstrate (i) that the Spanish media coverage is more homogenising than exclusive, although it presents both Islamophobic traits, and (ii) that it is more balanced in its framing of Muslims and Islam as a problem, and in fact it tends to portrays the Islamic as non-problematic. The democratic principle of pluralism of information is translated, in any case, into a plurality of frames. It is tentatively concluded that the media have the potential to foster tolerance by providing balanced coverage. The paper is expected to further contribute to comparative investigations.
\end{abstract}

Keywords: Spain, Islam, Muslims, Frame theory, Islamophobia.

\section{Introduction}

According to the Union of Muslim Communities in Spain (UCIDE, as in Spanish), the "Muslim population" residing in this South European country almost reached 1.95 million people (4.2\% of total population) in 2017 (UCIDE 2018), thus amounting to close four hundred thousand more people than six years before (UCIDE 2012). On the other hand, mostly Muslim Moroccans have become the largest immigrant community living in Spain. ${ }^{2}$ Like so many democracies, Spain has also experienced a rise in attitudes of rejection and hate incidents against Muslims along the last years. ${ }^{3}$ Europe as De Bellaigue (2018) points out "has become more anti-Muslim as it has become more Muslim". In his view, "as

\footnotetext{
${ }^{1}$ Research for this paper was funded by the Spanish Ministry of Economy, Industry and Competitiveness, research project num. DER2017-84178-P. An earlier version of this article was presented at the $17^{\text {th }}$ Annual International Conference on Politics (Athens Institute for Education and Research). The author acknowledge helpful feedback and comments from conference participants and invaluable suggestions from two anonymous reviewers.

*Associate Professor, University of Málaga, Spain.

${ }^{2}$ Official data are provided by the Spanish National Statistics Institute (https://www.ine.es).

${ }^{3}$ See the reports on Islamophobia in Europe by the Foundation SETA on http://www.islamophobia europe.com. As to the Spanish case, the annual reports by the Citizen Platform against Islamophobia are available at http://plataformaciudadanacontralaislamofobia.org.
} 
long as the Muslim population continues to increase so quickly, Islam will continue to cause apprehension among very large numbers of Europeans." 4

It is a widespread assumption, on the one hand, that liberal values and individuals of Islamic faith and/or culture (Muslims hereinafter) are incompatible. On the other, it is a common place to talk about 'the' Western opinion and attitude (as if unique) towards Muslims and Islam (M\&I hereinafter). ${ }^{5}$ By questioning both premises (Bowe and Makki 2016, Brown 2006, Greenberg and Miazhevich 2012), the aim of this study is to analyse the image(s) of M\&I that mass media are portraying to the public in Spain the extent to which the Spanish press is contributing to either inclusion or exclusion of Muslims as part of 'us', and thus to either the acceptance or rejection of 'them'. In other words, to what extent is the press imposing a dichotomous vision confronting 'us,' the Westerners, with 'them,' the Oriental 'other' (Said 1978), the strange 'other' (Bauman 2016), the Muslim 'other' (see also Said 1981)? There are empirical studies focused on other countries, but there is almost a research void regarding the Spanish case. ${ }^{6}$ As long as the media are relevant in the process of public opinion building, it is worth turning attention to the collective imaginary of M\&I they contribute to shape.

It is not unusual to find critical opinions by Muslims themselves over the distorted image that 'the' media portray of Islam, either in in-depth interviews (Butler-Sloss and Kessler 2015, Desrues and Pérez-Yruela 2008), in group discussions (Mijares and Lems 2018) or in surveys (Ameli and Merali 2015). Authors call for attention to the fact that this results in Muslims distancing themselves from the society which they are part of (Kunst et al. 2012). It is a critical comment usually made in generic terms, without empirical evidence to support it, and not merely on the part of Muslims. It is the case of Alba (a nonMuslim author) in stating that "the media have always portrayed Islam as a homogeneous and absorbent force (...) systematically described as threatening and negative" (Alba 2015: 69). Cebolla and González-Ferrer (2008: 251-252), on their own, contend that "the discriminatory tendency towards the Muslims at large throughout the European Union [is] a reflection of the deep-rooted stereotypes that are often echoed by the mass media" (see also Revenga and El Mouden 2010: 7).

The purpose of this study is to calibrate through quantitative content analysis such assumed bias. In trying to answer the empirical questions stated above, we will also ask the extent to which the media hold a unique or hegemonic narrative,

\footnotetext{
${ }^{4}$ In the same vein, even though with regard to immigration, Kaufmann and Goodwin have observed that opposition to immigration is higher the faster the rise of ethnic minority groups in relative terms (2018).

${ }^{5}$ It is widely assumed 'the West' to be the part of the World where liberal values are at the core of its identity. Scholars have gone deep into the complex and historical explanation of such an identity (Nemo 2005), while others challenge its very existence. Following Nemo, Western countries are most European countries, Canada, the United States, Australia, New Zealand, various European dependencies overseas, and maybe Israel. This paper does not intend either to uncritically assume such list of countries or that Latin American countries, for instance, are not part of the West. In using the terms 'the West' or 'Western' this paper is referring to non-majority-Muslim democracies that have experienced a double process during the last two decades: their Muslim population has increased as a result of international migrations and they have been attacked by terrorist Islamists as part of a war of civilizations.

${ }^{6}$ Martín et al. (1997) and Zurbano et al. (2017) address the issue.
} 
and whether possible differences among them are to be explained in ideological and/or territorial terms. We will analyse the coverage of three of the most-read Spanish newspapers: Abc, El País and La Vanguardia. The next section provides the theoretical framework of the paper. A section on methodology follows before we discuss our results. The last section concludes with the central findings of this research.

\section{Islamophobia: A Research Issue}

M\&I have reached a Western media presence in the XXI century unacknowledged previously. It has been a quantitative but also a qualitative change. Even though the paradigm shift is previously observed (Brown 2006), it is since the terrorist attacks on the USA on September 11, 2001, that the framing of M\&I as linked to fanaticism and a threat to the West becomes hegemonic (Ruigrok and Van Atteveldt 2007). ${ }^{7}$ It happens to the detriment of the previously hegemonic image of the Islamic as exotic and sensual. As Berbers et al. (2016) have put it, it is a tendency of the news sector in covering M\&I that goes hand in hand with the growing Islamophobia. For Corm (2004), a false dichotomy or "fracture imaginaire" has been imposed between the West, 'us,' and the East, 'them' (see also Ibrahim, 2010, Saeed 2007). With the incidents of 9/11 acting as a catalyst, media discourse is evoking Said's Orientalist approach (1978), that is, they are covering Muslim people as an 'other' to be rejected and fearful of (Ahmed and Matthes 2016, Creutz-Kämppi 2008). Even though recognising the contribution of Said, authors such as Corral (2014: 8) understand that using the term 'Islamophobia' is more appropriate than talking about Orientalism.

Islamophobia is a form of racism. It implies the rejection of Muslims, not because of their phenotypic traits, but because of their religious and/or cultural identity. Anti-Islamic racism is a narrative, an attitude, and/or a behaviour that should not be confused with criticism of Islamic issues (Imhoff and Recker 2012). It implies a rejection of Muslims as such in their entirety. In the extreme, such a form of hatred implies a desire for Muslims to go badly or that, in being so different from the 'us' who rejects them (either by fear or hatred), do not enjoy 'our' goods. It is usually understood that Islamophobia is given with suspicion and rejection, thus without the need for the desire for evil to be present.

The first Runnymede report (Richardson 1997) has become a landmark of studies on Islamophobia (see i.e., Anderson 2015, Bowey and Makki, 2016). It defines "unfounded hostility towards Islam, and therefore fear or dislike of all or most Muslims" as a constellation of eight aspects of "closed" vs. "open" views of Islam: (1) whether Islam is seen as monolithic and static, or as diverse and dynamic; (2) as other and separate, or as similar and interdependent; (3) as inferior, or as different but equal; (4) as an aggressive enemy or as a cooperative partner; (5) as manipulative or as sincere, as well as (6) whether Muslim criticisms of 'the West' are rejected or debated; (7) whether discriminatory behaviour against

${ }^{7}$ As to the USA, the Dutch and the British cases, see respectively Nacos and Torres-Reyna (2007), Roggeband and Vliegenthart (2007), and Baker et al. (2013a). 
Muslims is defended or opposed, and (8) whether anti-Muslim discourse is seen as natural or as problematic.

Alba (2015) has synthesised those eight aspects of Islamophobia into three "mechanisms" by means of which it is built "an 'other' which is manipulable and eventually exterminable": the reduction of the Muslim 'other' to a negative (a threatening actor) and "unassimilable" ("incurable") unit (a homogeneous agent). Regarding refugees, Chouliaraki and Zaborowski's (2017) three "narrative strategies" of "symbolic bordering" of the 'other' are analytically interesting: "silencing" (the omission of voice in the media discourse), "collectivization" (the reduction of the individual to undifferentiated member of a presumed community), and "decontextualization", or absence of contextualization of the phenomenon when framing it. By focusing on the populist dimension of Islamophobia, Hafez $(2017,2010)$ has introduced the concept of Islamophobic populism. He refers to the populism that sees the people threatened, not by a perverse elite, but by Islam. Like many others, this author understands that Islamophobes perceive Islam as a homogeneous, static and monolithic body, on the one hand, and, on the other, as reactionary, hostile, etc.

Most empirical studies on media coverage of M\&I attend to the positive or negative image that is portrayed of them. In their review of the literature, Ahmed and Matthes (2016) have concluded that both the negative representations and the national topic of the integration of the Muslims - addressed as a problem as well are common to the countries under research. As Kaya (2017) has summed up, for more than a decade most immigrants of Muslim background and their descendants in European societies are often associated with illegality, crime, violence, drugs, radicalism, fundamentalism, conflicts and many other aspects because of which they are represented in a negative way. In their longitudinal case study of the Dutch press, Roggeband and Vliegenthart (2007) observed that the Islamic aspect appears in a prominent way as a threat to national norms and values.

It is so because of issues such as the separation of church and state, homosexuality, gender equality and freedom of expression. Thus, the "threat to cultural security" on the part of the Muslims (Berbers et al. 2016, Kaya 2017: 60) is added to the threat to physical and economic security, so present in the media discourse about immigration. Islamic clothing use to be portrayed as a challenge to the prevailing dress codes of secular or non-Muslim society. The discourse opposes Islam to the values of the Enlightenment and even to the values of Christianity (Creutz-Kämppi 2008), ${ }^{8}$ and it has nourished criticism of multiculturalist policies in favour of assimilationist ones (Keskinen, 2014). As a result, public opinion would not be exposed to the knowledge of the differences of an equal fellow citizen, but to the othering of him/her/them. The Muslim 'other' turns out to be a "menacing stranger" (Creutz-Kämppi 2008: 298, see also Bauman 2016).

\footnotetext{
${ }^{8}$ Ash (2017) observes that xenophobic right-wing nationalists do not think of liberal values when they fear Muslim threat to their culture. According to him, they define their identity in ethnocultural terms. That is why, in talking about Germany, he counterposes Kultur to Zivilisation.
} 


\section{News Media Framing of Muslims and Islam}

Journalism "is about doing things with words, not simply about using words to report facts" (Chouliaraki 2013: 268). It acts on people's perceptions of reality, so it is a "performative practice" (Chouliaraki and Zaborowski 2017: 616). Mass media use three fundamental mechanisms when informing and shaping public opinion: they select the issues to be considered as news (thus contributing to set the agenda of topics of public interest), hierarchise them, and adopt a point of view, namely, the media help to understand and confer a meaning on the reported issues and their implications. The quantitative analysis of these aspects of journalistic work (content analysis) and their impact on power relations is carried out through the respective agenda-setting theory, priming theory and framing theory. In Entman's (2007: 163) words, they three are "critical tools in the exercise of political power". As to M\&I, the academic production is mostly based on the framing theory. It is a field of study still to be explored regarding the Spanish case. This paper attempts to fill that void.

Authors who study media coverage by focusing on frames do analyse the extent to which the media, in addition to setting the public agenda of topics, induce in the public a way of understanding such issues (De Vreese et al. 2011, Scheufele and Iyengar 2011, Scheufele and Tewksbury 2007). The media do not only represent or mirror reality; they mostly frame it. Given that any news can be covered in different ways, and since the way in which it is covered by the media conditions the cognitive and attitudinal processing, frames are what leads to interpreting the same issue differently based on the one adopted. According to the classic definition by Entman (1993), framing entails defining problems, diagnosing causes, making moral judgements, and suggesting remedies. The definition of the problem or issue implies the identification of the group or individual (the subject). It is an aspect that in turn has made it advisable to attend to sources and voices which news texts are elaborated with, especially in order to see the extent to which the subjects themselves are present in the stories, namely, whether or not they are "subjects of voice" (Chouliaraki and Zaborowski 2017). ${ }^{9}$ It is through all such a mechanism that the media certainly do not determine (Bowe et al. 2015), but induce opinions, attitudes and ultimately behaviours.

Media effects on those who are exposed to them is also observed regarding M\&I. Ahmed and Matthes (2016) confirm in their review of the literature that the 2004-2008 increase in Islamophobia in the USA can be explained in relation to the different media treatment of M\&I, being more prejudiced than in Europe. Saleem et al. (2015) have experimentally proven that citizens are more likely to support policies that harm Muslims the more they are exposed to coverage that represents them as terrorists. ${ }^{10}$ The authors add that, whereas affecting perceptions and attitudes in the medium term regardless of the ideology, media coverage mainly

\footnotetext{
${ }^{9}$ Felicetti and Gattinara (2018) have observed in their analysis of The Guardian's coverage of the Charlie Hebdo January 2015 terrorist attacks that women and religious groups, Muslims in particular, had limited visibility, such as the actors who questioned the dominant security narrative.

${ }^{10}$ As to the media stories on immigration, Givens and Luedtke (2005) have found that the mere increase of them contributes to making the corresponding policies more restrictive.
} 
affects conservatives in the short term. McElwee and McDaniel (2015) have documented that, while Republicans in the USA have a higher perception of Muslim as violent people than Democrats, the gap between them is reduced and the negative perception by both groups increases when they regularly watches Fox News TV channel. ${ }^{11}$ With respect to public policies, Uitermark and Giele (2010) have concluded, in a case study, that national authorities do not act against radicalism in mosques because it is the problem of a neighbourhood, but because of being impelled to by media coverage.

Roggeband and Vliegenthart (2007) have identified five frames in their comparative study of Dutch media and political discourses about immigration and the integration of immigrants. Whereas only one of them is positive - the "multicultural" frame - making the other four frames a problem out of immigration, the one that has gained the most presence since 9/11 is the "Islam-asthreat" frame. Such a frame focuses on values and culture (see also Chouliaraki and Zaborowski 2017). In another paper on the Netherlands, D'Haenens and Bink (2007) have found that media frames negatively problematise both the economic consequences and issues of morality when addressing M\&I. With regard to framing in the USA, Greenberg and Miazhevich (2012: 91) have pointed out in analysing the New York Times "a shift from a sympathetic tone toward British Muslims to an open hostility to and an 'Othering' of Britain". Islam became the salient aspect of British Muslim identity after 9/11, and the UK was generally portrayed as "an unequal partner in the fight against Islamic extremism, weakened by its home-grown terrorism" (Greenberg and Miazhevich 2012: 92).

The predominance of a given frame, the negative one, does not imply it to be the only one. Roggeband and Vliegenthart (2007) have found a variety of frames, even though media framing appears less varied compared to parliamentary framing. Anderson (2015: 265) has compared Australian coverages on M\&I by differentiating between "open" and "closed" frames, ${ }^{12}$ and she has observed a variation in time in favour of the former; in her view, as a reaction to critics of "unfair, unbalanced, and inflammatory reporting" on issues related to M\&I in the mid-2000s. Bowe et al. (2015) have also studied the USA coverage after 9/11 in binary terms, in their case by attending to the tone: "positive" vs. "negative" frames. The authors have concluded that, whereas negative framing prevails, neutral framing is the one with the greatest presence. In line with Bowe et al. (2015), Bowe and Makki (2016: 551) have concluded in studying mosques as a matter of public debate that "it would be an oversimplification to say representations of Muslims are uniformly negative".

While Muslims are mostly ill-treated in media coverage, scholars have also obtained evidence that the diversity and frequency of frames varies according to the editorial line (left or right), the type of newspaper (tabloid or broadsheet) and the territory, at least in the case of countries with sub-state nationalisms. Through

\footnotetext{
${ }^{11}$ See Eyssel et al. (2015: 197) on how the biased TV representation of Muslims is "one important factor in the widespread emergence and existence of Islamophobia in Germany".

${ }^{12}$ Chouliaraki and Zaborowski (2017: 615), worried about the definition of 'us,' differentiate between the "cosmopolitan" frame ("open, hospitable and inclusive") and the "communitarian" one, which they describe as "closed, phobic and introverted".
} 
critical discourse analysis, Baker et al. $\left(2013^{\mathrm{a}}, 2013 \mathrm{~b}\right)$ have observed a more balanced coverage in the left-oriented newspapers and a greater tendency to associate Islam and terrorism among the tabloids. Scalvini (2016: 624) points out that the conservative press expresses "a preoccupation with the rising cultural and religious diversity," whereas progressive dailies are "more focused on promoting social cohesion and pursuing the joint goals of inclusion and integration". Berbers et al. (2016) have documented that quality newspapers and those on the left adopt less problematic frameworks than tabloids and right-wing broadsheets. Focusing on Muslims living in Belgium who went to Syria to fight against Bachar al-Assad in 2013, they have also observed, firstly, that the frames that problematise the Syria fighter situation are used much more frequently than the other frames; secondly, that Flemish newspapers pay more attention to the matter, and, lastly, that they covered it - compared to the thematic or contextualising option - more by the episodic frame than the Dutch press.

\section{Research Object and Design}

Van Dijk (2004: 351 as cited in Hafez 2017: 396) differentiates between racist discourse directed at (the racialised) 'others' and racist discourse about (the racialised) 'others'. The object of this study is that second discourse; in particular, it tries to assess the extent to which the media discourse on M\&I in Spain makes Muslims a strange 'other,' an 'other' to be suspicious of and to reject, no matter whether they are explicitly wished ill or not. In other words, it aims to analyse whether Islamophobic framing also predominates in the Spanish press or, on the contrary, the pluralism of information is translated into a diversity of frames and even a predominance of the integrative one. Neither all Muslims are the same nor Muslims are only defined by their religious dimension. To be more precise, the question at the backbone of this research is whether and to what extent the Spanish media discourse constructs a homogenising, excluding and problematising imaginary of M\&I.

This triple combination is what ultimately characterises Islamophobia (see above). Our study is of a deductive nature (Semetko and Valkenburg 2000). We analyse the extent to which the three pre-defined frames occur in the news. As shown in Figure 1, it will be analysed the presence of the inclusive frame - the subject as being part of the reference 'us' - vs. the exclusive frame, thus the subject being a strange 'other.' Secondly, it will be measured the extent to which M\&I are assumed as a homogeneous whole or as a heterogeneous reality. Lastly, we will assess the extent to which the adopted frame problematises M\&I or not. Given that the selection of news stories is based on the coverage of M\&I, the database introduces a religious bias, so the extent to which the press reduces individuals of 'perceived' Mohammedan faith or cultural identity to its religious dimension - another Islamophobic trait - will not be studied.

Media discourse is not merely constructed according to one of the frames of each pair, but also as an invalidation of the other one. In those cases, the terms and/or texts of the research are coded as the frame alternative to the one that is 
invalidated in a given document. On the other hand, the messages transmitted by journalists can also be confusing, ambivalent or imprecise. In such occasions, given the impossibility or difficulty of determining a given frame, it can be concluded that the information coverage does not tend to shape public opinion in one way or another. Those terms and/or texts are coded as of a third frame and labelled as 'neutral' (Anderson 2015, Bowe et al. 2015). ${ }^{13}$

As a first hypothesis, it is expected that the predominant frame would be Islamophobic (H1), although it is foreseeable of media coverage to be plural in terms of frames (H2) and left-wing outlets both to be more plural than those on the right and covering M\&I according to the integrative frame to a larger extent (H3), with the centrist dailies in an intermediate position. Furthermore, although the centrist newspaper of the study is not Spanish in a territorial sense, but clearly Catalan, ${ }^{14}$ ideology is expected to weigh more in framing M\&I than territoriality (H4), in coherence with other studies (Durán 2016) and despite the amount of people with perceived-Muslim identity residing in Catalonia (UCIDE 2018). Finally, we cannot expect that each media outlet frames uniformly all the issues that it covers about M\&I (H5), so possible internal variations and coincidences among dailies will also be analysed.

To answer the question of the research and test the hypotheses, a matrix has been elaborated from the reviewed literature, mostly from Nickels' (2007) approach (see also Entman 1993). It allows to identify and quantify how the Spanish press frames M\&I. Three analytical categories (first column on the left in Figure 1) determine media coverage of M\&I as to framing: (1) the identification of the subject (how M\&I are framed); (2) the voices and sources of the discourse (from whom the newspapers feed to build their narrative), and (3) the definition or identification of the news object (what topic or issue is addressed). For the first category, the entries "Islam*" and "Muslim*" are coded. The second category implies the codification of all the terms used to specify the persons, organizations or institutions whose opinion is reported, either in direct or in indirect style, that is, whether voices or sources, respectively. As to the third category, the topics of the news are codified in each of the texts. The resulting matrix allows assessing the adopted frame (one of each pair showed in the central column of Figure 1) for each of the categories. The first element of each pair corresponds to the Islamophobic frame, while the second one does to the integrative frame. The systematisation of the analysis - 5,083 words or sets of words have been coded has been done using the Atlas.ti software.

\footnotetext{
${ }^{13}$ We avoid the neutral frame in Figure 1 for the sake of clarity.

${ }^{14}$ Catalonia is a region of Spain.
} 
Figure 1. Analytical Matrix of Muslims and Islam Media Framing

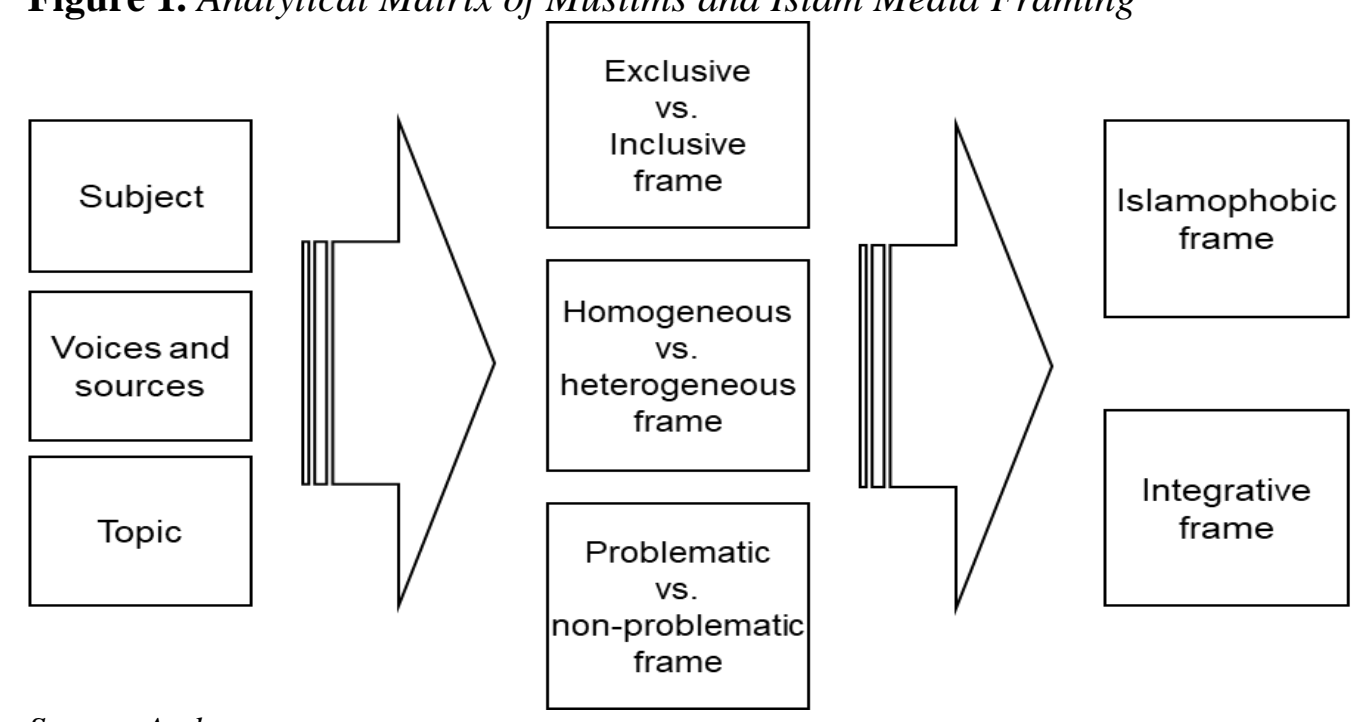

Source: Author.

Many studies focus on the coverage of concrete events, which often receive attention due to the tensions or conflicts around them: construction of mosques (Bowe and Makki 2016), cartoons of Muhammad (Creutz-Kämppi 2008), prohibition of the use of the integral veil (Fernández-Suárez 2016), etc. On the contrary, this study focuses on the normality that is mediatically constructed over a period of time; specifically, the twelve months of 2017. That normality is what becomes Bourdieu's concept of 'habitus,' the 'common sense' of each historical time (1994). After 9/11 and the subsequent Spanish 11-M attacks, ${ }^{15} 2017$ is not a conflictive year over M\&I issues. Even the humanitarian crisis of either migratory flows or forced displacement (being the refugees arriving in Europe mostly Muslims) reduced its media impact after having been more acute in 2015 . $^{16}$ During 2017, on the other hand, jihadist attacks continued to be perpetrated, but they did not convulse or receive the same media attention as before (De Bellaigue 2018); neither did they in the case of attacks in Catalonia, in August. These terrorist incidents make the study of that year more relevant, insofar as such a unique event altered the coverage and in what sense. All that makes of 2017 an optimum year for the study.

The analysis focuses on three of the six Spanish general information newspapers with the most daily readers throughout 2017: from highest to lowest readers, 'El País' (EP hereinafter), 'La Vanguardia' (LV) and 'Abc' (ABC). According to the General Media Survey (EGM, as in Spanish), ${ }^{17}$ 'El Mundo' (EM) was the second most widely read newspaper; LV shared the third and fourth

\footnotetext{
${ }^{15}$ After New York, Madrid was the largest Western city to suffer jihadist attacks, on 11th March 2004. London would follow them in 2005. From then on attacks have occurred in the same and other Western cities.

${ }^{16}$ Data of the United Nations High Commissioner for Refugees can be consulted at https://data2.un hcr.org/en/situations/mediterranean.

${ }^{17}$ EGM depicts a scenario of media consumption in Spain through 30.000 personal "face to face" interviews with results disclosed in April, July and December. EGM has been established as the establishment survey in the Spanish market. EGM reports can be consulted at http://www.aimc.es.
} 
positions with the Galician 'La Voz de Galicia', while ABC shared the fifth and sixth positions with the Catalan 'El Periódico'. Out of the six, those in the study are also the three whose website had a greater number of unique visitors throughout the period. The election of the three broadsheets is also justified by both their ideological orientation and their editorial headquarters: right-wing ABC and left-wing EP are edited in Madrid and have a national projection (like rightwing EM), whereas centrist LV is published in Barcelona and is markedly Catalan. ${ }^{18}$ This aspect is interesting, above all, because Catalonia (unlike Galicia) is the Spanish region with the greatest presence of Muslims, a variable that could affect media framing and justify one of our hypotheses.

Our database is made up of the press clippings in which the terms "Islam*" and/or "Muslim*" appear. While most studies focus on these two (Bowe et al. 2015), we add to our search "veil*," "scarf*," "hijab*," "niqab*," "burka*," "mosque*," "minaret*," and "imam*." We have used the MyNews digital archive. Regarding the news on international issues, the clippings that have been incorporated into the documentary corpus are those using the search terms in the headlines, in the sub-titles, in the leads, in the pull-quotes or in the captions; they are the texts in which, to some extent and whatever the issue and the framing, the topic is Islamised. Insofar as the study of the coverage of jihadist terrorism is a research field in itself and in order to avoid research bias, the journalistic pieces about it and about war conflicts in Muslim-majority countries are discarded. Once the extemporaneous texts located by MyNews have also been discarded, the documentary base is finally made up of 432 analysis units.

\section{Results}

\section{Descriptive Approach to Media Coverage}

Our database assembles the journalistic attention provided by ABC, EP and LV to the Islamic throughout 2017. As it is shown in Table 1, EP covered contents on M\&I to a lesser extent than $\mathrm{ABC}$ and LV. The differences among the newspapers is more marked by type of analysis unit: although the three mostly opt for news and reports, more than half of the total front pages, editorials and letters to the editor are by ABC. The right-wing daily also surpasses EP and LV in the opinion space with more entries: op-eds and columns.

Media coverage is regularly distributed throughout the year, with records accumulated in just over half of the days (see Table 1). LV is the newspaper that devotes attention to Islamic issues for more days (less than a third of the 365 total). Just one entry per day is recorded in $67 \%$ (ABC and LV) and in 70\% (EP) of those days with coverage. $\mathrm{ABC}$ only collects more than two entries in 17 editions, 10 and 8 in the case of EP and LV, respectively. Barely four Spanish news stories provoke more than two pieces of coverage in the same day, be they from the same newspaper or from more than one: the decision of a court endorsing the right of a

${ }^{18}$ For more information on the ideological orientation of the Spanish media, see Humanes (2014) and Durán (2016). 
woman to wear the hijab in her workday and the prohibition an inmate for jihadism to use it, the campaign of the diocese of Cordoba in defence of the property and catholicity of the Mosque-Cathedral of the same city, and the terrorist attacks of August in Barcelona and Cambrils, being the latter a close and popular seaside resort town.

Table 1. Media Attention by Words, Days, Documents and Type of Documents (Year 2017)

\begin{tabular}{|c|l|c|c|c|c|c|c|c|}
\hline & & $\begin{array}{c}\text { Total } \\
(3 \\
\text { dailies })\end{array}$ & \multicolumn{2}{|c|}{$A b c$} & \multicolumn{2}{c|}{ El País } & \multicolumn{2}{c|}{ La Vanguardia } \\
\hline & & & Total & $(\%)^{*}$ & Total & $(\%)^{*}$ & Total & $(\%)^{*}$ \\
\hline \multirow{2}{*}{} & Total & 432 & 152 & $35.2 \%$ & 130 & $30.1 \%$ & 150 & $34.7 \%$ \\
\cline { 2 - 10 } & $\begin{array}{l}\text { Front } \\
\text { pages }\end{array}$ & 8 & 5 & $62.5 \%$ & 2 & $25.0 \%$ & 1 & $12.5 \%$ \\
\cline { 2 - 10 } \\
$\begin{array}{l}\text { News / } \\
\text { reports }\end{array}$ & 325 & 103 & $31.7 \%$ & 110 & $33.8 \%$ & 112 & $34.5 \%$ \\
\cline { 2 - 10 } \\
$\begin{array}{l}\text { Op-eds / } \\
\text { columns }\end{array}$ & 70 & 32 & $45.7 \%$ & 15 & $21.4 \%$ & 23 & $32.9 \%$ \\
\cline { 2 - 10 } & $\begin{array}{l}\text { Letters to } \\
\text { the editor }\end{array}$ & 12 & 8 & $66.7 \%$ & 1 & $8.3 \%$ & 3 & $25.0 \%$ \\
\cline { 2 - 10 } & Editorials & 7 & 4 & $57.1 \%$ & 1 & $14.3 \%$ & 2 & $28.6 \%$ \\
\cline { 2 - 10 } & Interviews & 10 & 0 & $0.0 \%$ & 1 & $10.0 \%$ & 9 & $90.0 \%$ \\
\hline Words & & 246,800 & 77,581 & $31.4 \%$ & 73,527 & $29.8 \%$ & 95,691 & $38.8 \%$ \\
\hline Days** & & 200 & 85 & & 86 & & 105 & \\
\hline
\end{tabular}

Source: Author.

*Percentages of row, with respect to the corresponding total of the three newspapers.

**Days with news in the database. The sum of the days of coverage of each newspaper totals more than 200 because there are days when two or three newspapers coincide with news about Muslims and/or Islam.

The other news that have received more attention in the same day are related to the dress of Muslim women (burka or hijab); to the verdict of the Strasbourg Court on the obligation of minors to attend their swimming school classes independently of their religious beliefs; to the Islamophobic attacks in Canada and the UK; to the executive order of the USA President prohibiting the entry from several Muslim-majority countries, as well as to his official visit to Saudi Arabia and his relationship with the Islamophobic organization Britain First; to the Dutch general elections; to the papal trip to Egypt, and to the flee of Rohingya from Burma to Bangladesh. Of all of them, only the pontifical visit and the attacks in the UK (Islamophobe) and Spain (jihadist) were the predominant news for more than a day, seven in the case of the latter (see above). 


\section{Analytic Categories and Media Frames}

The above data hardly allow to deduce the citizens' opinions that the media tend to shape. In order to analyse the frame adopted by the media in addressing issues related to Islam - or in Islamising news contents - we have introduced 100 codes. ${ }^{19}$ This has resulted in a total of 22,296 coded records. The next section analyses the frame adopted by the newspapers when referring to M\&I as subjects of the published information and opinions. We then address, first, the voices and sources on which the journalistic pieces are based to sustain their discourse, and, in the third section, the topics they address, while also analysing the frames adopted in each of these categories.

\section{The Islamic Subject of Media Discourse}

Table 2 shows the frames adopted by the newspapers whenever they refer to Islam or Muslims as a subject, be it individual or collective, and personal or institutional. Having coded more than 5,000 records in this regard, it is observed that the coverage mostly frames M\&I as a subject unrelated to 'us' (exclusive frame). The data is all the more significant given that journalistic references regarding Muslim-majority countries have been excluded from this computation when addressing issues in which 'us' does not participate. ${ }^{20}$ Also noteworthy is the high percentage of records with a neutral frame, superior to the inclusive one. They are the occasions in which, when referring to M\&I, it is not made explicit if they are considered part of or alien to 'us.'

As to the second trait of Islamophobia, the media mostly homogenises M\&I. In this case, in addition, it is found that the neutral frame is not very present. On the contrary, and against the problematisation of the Islamic that characterises Western media coverage, in the Spanish case (i) there is a balance between problematic and non-problematic frames of the Islamic subject, and (ii) the problematic frame is present to a lesser extent than the other two Islamophobic ones.

In a complementary way, the binary variants of each frame (inclusive vs. exclusive, etc.) do not only have a significant presence in the global calculation of media coverage, but also in the units that comprise it: all the frames are present in at least $32 \%$ of the 380 documents in which an explicit reference is made to the Islamic subject (see Table 3). The articles with the subject framed in an exclusive way predominate over those with entries framed inclusively. However, the texts that contain records with either the subject framed in a heterogeneous way - not all Muslims are the same - and/or non-problematic are more than their Islamophobic variant. There are, therefore, a diversity of frames, and it is not the Islamophobic

\footnotetext{
${ }^{19}$ As presented above in the methodology and it is analysed below, codes have been introduced for each of the categories, frames, newspapers, and kind of document (op-ed, column, interview, and so on), as well as for the different voices and sources (plus whether they are Muslim or not), the different territories at stake in the texts, and the different topics in the news.

${ }^{20}$ It is the case of the news entitled "Morocco starts the fight against the burqa" (EP, 11 January 2017, p.2) and "Morocco prohibits importing, manufacturing and selling burkas in the country" (LV, 11 January 2017, p.6).
} 
ones that predominate. Regarding the greater frequency of homogenising records mentioned above, the analysis of their distribution indicates, finally, that those records are concentrated in just over a third of the articles.

Table 2. Media Frame of Muslims and Islam as 'Subject': Codified Records of Each Frame (2017)

\begin{tabular}{|c|c|c|c|c|c|c|c|c|}
\hline & \multicolumn{2}{|c|}{3 dailies } & \multicolumn{2}{|c|}{$A b c$} & \multicolumn{2}{|c|}{ El País } & \multicolumn{2}{|c|}{ La Vanguardia } \\
\hline & Records & $\% *$ & Records & $\% *$ & Records & $\% *$ & Records & $\% *$ \\
\hline $\begin{array}{l}\text { Inclusive } \\
\text { frame }\end{array}$ & 369 & $24.5 \%$ & 104 & $17.6 \%$ & 167 & $40.5 \%$ & 98 & $19.5 \%$ \\
\hline Neutral frame & 403 & $26.8 \%$ & 125 & $21.2 \%$ & 114 & $27.7 \%$ & 164 & $32.6 \%$ \\
\hline $\begin{array}{l}\text { Exclusive } \\
\text { frame }\end{array}$ & 734 & $48.7 \%$ & 362 & $61.3 \%$ & 131 & $31.8 \%$ & 241 & $47.9 \%$ \\
\hline $\begin{array}{l}\text { Heterogeneous } \\
\text { frame }\end{array}$ & 543 & $27.9 \%$ & 157 & $22.4 \%$ & 170 & $31.4 \%$ & 216 & $30.8 \%$ \\
\hline Neutral frame & 114 & $5.9 \%$ & 35 & $5.0 \%$ & 32 & $5.9 \%$ & 47 & $6.7 \%$ \\
\hline $\begin{array}{l}\text { Homogeneous } \\
\text { frame }\end{array}$ & 1,287 & $66.2 \%$ & 510 & $72.6 \%$ & 339 & $62.7 \%$ & 438 & $62.5 \%$ \\
\hline $\begin{array}{l}\text { Non- } \\
\text { problematic } \\
\text { frame }\end{array}$ & 770 & $39.6 \%$ & 197 & $28.1 \%$ & 312 & $57.7 \%$ & 261 & $37.3 \%$ \\
\hline Neutral frame & 400 & $20.6 \%$ & 148 & $21.1 \%$ & 98 & $18.1 \%$ & 154 & $22.0 \%$ \\
\hline $\begin{array}{l}\text { Problematic } \\
\text { frame }\end{array}$ & 772 & $39.8 \%$ & 356 & $50.8 \%$ & 131 & $24.2 \%$ & 285 & $40.7 \%$ \\
\hline Total & 5,392 & & 1,994 & & 1,494 & & 1,904 & \\
\hline
\end{tabular}

Source: Author.

*Percentages of column and by group of frames.

The disaggregation of register data by newspaper (Table 2) reveals relevant differences: in both $\mathrm{ABC}$ and LV the presence of each Islamophobic frame is greater than that of the integrative one, although the differences in percentage points between each binary variant are always superior in ABC (rightist and edited in Madrid) than in LV (centrist / Barcelona). On the contrary, EP (leftist/Madrid) reports on the Islamic subject with a predominance of inclusive and nonproblematic frames. Yet, while the homogeneous records surpass the heterogeneous ones in EP as well, the difference in percentage points is the smallest of the three dailies.

The homogeneous frame does not always have a negative connotation. It is certainly wrong and harmful to refer to Muslims as an internally undifferentiated community. It is also true that they are occasionally referred to in such terms without any Islamophobic connotation. This was the case, for example, when the press quoted the Canadian prime minister as saying about an extreme right attack in Quebec that it was perpetrated "against the Muslim community." He added: "we will stand with you", and also: "you enrich our shared country in immeasurable ways." 21 In homogenising them, he expressed a conception of 'us' that included them (inclusive frame, therefore), and, far from seeing them as a problem, they were the object of a violence that he rejected (non-problematic frame).

\footnotetext{
${ }^{21} \mathrm{ABC}, 31-01-2017$, p.26.
} 
Table 3. Media Framing of Muslims and Islam as Subject: Documents with Coded Records of Each Frame (Year 2017)

\begin{tabular}{|l|c|c|c|c|c|c|c|c|}
\hline & \multicolumn{2}{|c|}{3 dailies } & \multicolumn{2}{c|}{ Abc } & \multicolumn{2}{c|}{ El País } & \multicolumn{2}{c|}{ La Vanguardia } \\
\hline & Documents & $\% *$ & Docs. & $\% *$ & Docs. & $\%{ }^{*}$ & Docs. & $\% *$ \\
\hline $\begin{array}{l}\text { Inclusive } \\
\text { frame }\end{array}$ & 123 & $32.4 \%$ & 38 & $28.6 \%$ & 40 & $35.4 \%$ & 45 & $33.6 \%$ \\
\hline Neutral frame & 180 & $47.4 \%$ & 72 & $54.1 \%$ & 46 & $40.7 \%$ & 62 & $46.3 \%$ \\
\hline $\begin{array}{l}\text { Exclusive } \\
\text { frame }\end{array}$ & 174 & $45.8 \%$ & 57 & $42.9 \%$ & 49 & $43.4 \%$ & 68 & $50.7 \%$ \\
\hline $\begin{array}{l}\text { Heterogeneous } \\
\text { frame }\end{array}$ & 179 & $47.1 \%$ & 53 & $39.8 \%$ & 59 & $52.2 \%$ & 67 & $50.0 \%$ \\
\hline Neutral frame & 329 & $86.6 \%$ & 116 & $87.2 \%$ & 92 & $81.4 \%$ & 121 & $90.3 \%$ \\
\hline $\begin{array}{l}\text { Homogeneous } \\
\text { frame }\end{array}$ & 143 & $37.6 \%$ & 42 & $31.6 \%$ & 48 & $42.5 \%$ & 53 & $39.6 \%$ \\
\hline $\begin{array}{l}\text { Non- } \\
\text { problematic } \\
\text { frame }\end{array}$ & 248 & $65.3 \%$ & 69 & $51.9 \%$ & 87 & $77.0 \%$ & 92 & $68.7 \%$ \\
\hline Neutral frame & 249 & $65.5 \%$ & 97 & $72.9 \%$ & 58 & $51.3 \%$ & 94 & $70.1 \%$ \\
\hline $\begin{array}{l}\text { Problematic } \\
\text { frame }\end{array}$ & 204 & $53.7 \%$ & 68 & $51.1 \%$ & 54 & $47.8 \%$ & 82 & $61.2 \%$ \\
\hline Total & 380 & & 133 & & 113 & & 134 & \\
\hline
\end{tabular}

Source: Author.

*Percentage with respect to the total documents with subject records and by group of frames.

The diversity of frames is also observed in Table 3 with all the frames present in the three newspapers, the frame that appears in less documents is present in at least $29 \%$ of them. While the three newspapers published more pieces containing records of exclusive frame than of inclusive one, the other two Islamophobic frames are less present than their integrative counterparts. Even though there are few differences among the dailies regarding the homogeneous/heterogeneous frame, the presence of non-problematic records is seen in $77 \%$ of EP documents, 29 points above the percentage of documents of the same newspaper with problematic records. In this respect, LV appears less integrative than EP, but more so than $\mathrm{ABC}$, which balances the number of documents in which conflicting $(n=68)$ and non-conflicting $(n=69)$ frames are recorded.

\section{Voices and Sources in Building the Islamic}

As it is showed in Table 4, the media discourse is built on the basis of voices and sources (V\&S hereinafter) in 350 out of our 432 documents. They include public institutions and authorities, civil society members and leaders, experts, celebrities and anonymous or unknown people (vox populi). We have additionally differentiated V\&S depending on whether they are Muslims or not, in order to check the extent to which Muslims' voice is shared with those exposed to the media. 
Table 4. Voices and Sources in the Coverage of the Islamic (Year 2017)

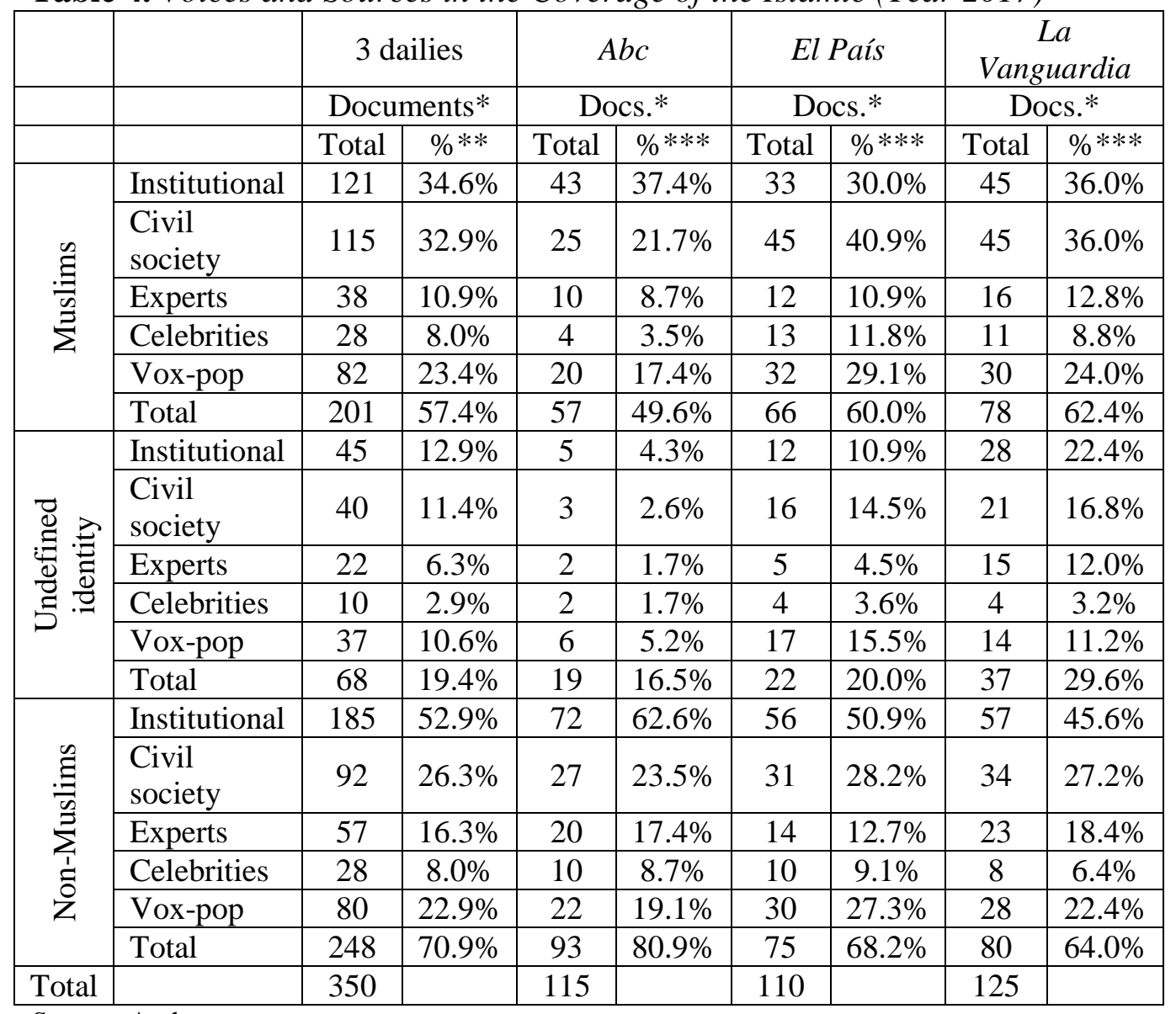

Source: Author.

*Documents with coded records of voices and sources $(\mathrm{V} \& \mathrm{~S})$. The totals that are showed in four rows (horizontally) do not match with the numbers in their respective columns (vertically) because documents often contains more than one voice or source of a different kind.

** Percentages with respect to the total of documents with V\&S records $(\mathrm{N}=350)$.

***Percentages with respect to the total of documents with V\&S records of each newspaper $(\mathrm{NABC}=115, \mathrm{NEP}=110$ y NLV=125)

Opinions and testimonies of non-Muslims appear in $71 \%$ of the texts (see Table 4). Although the amount of those that give voice to the Muslims is lower, they are collected in more than half of the documents. Whether Muslim or not, institutional V\&S predominate. The other actors are also present, especially civil society agents, followed by vox-pop. Non-Muslim institutions, in any case, are the unique actor present in more than half of the texts. By newspapers, Muslim V\&S occur in less documents in ABC than in any other. The righ-wing daily is also the one that leaves the actors without religious identity ascription in fewer texts and the one that incorporates non-Muslim institutional V\&S to a larger extent. No significant differences appear between EP and LV. And, while both dailies expose their readers to Muslim V\&S in more than $60 \%$ of their documents, the texts with non-Muslims V\&S are at least 13 points below the coverage that gives them ABC.

The inclusive and the exclusive frames have a balanced presence, although non-Muslim V\&S stand out with an exclusive discourse (see Table 5). The 
predominance of the Islamophobic frame is greater when attending to the homogeneous/heterogeneous frames, with a presence of non-Muslim V\&S much more accentuated in this case (61\% of documents). On the contrary, the problematic frame does not predominate. It is rather balanced with the non-problematic one, no matter whether V\&S are Muslim or non-Muslim. ABC is less inclusive than LV, which in turn is less inclusive than EP. Actually, the leftist daily is the most inclusive regardless of whether V\&S are Muslim or non-Muslim. Even so, the three are more exclusive than inclusive, and it is LV that publishes the greatest number of documents with V\&S in Islamophobic frame. In line with the inclusive frame, $\mathrm{EP}$ is also the newspaper that covers Muslims as a heterogeneous collective in more texts in relative terms. It follows LV. ABC incorporates such V\&S in less than a third of its documents.

Table 5. Voices and Sources in the Media Framing of the Islamic (Year 2017)

\begin{tabular}{|c|c|c|c|c|c|c|c|c|}
\hline & \multicolumn{5}{|c|}{3 dailies } & $\mathrm{ABC}$ & EP & $\mathrm{LV}$ \\
\hline & & Docs.* & & $\begin{array}{c}\text { Doc } \\
\text { s. }\end{array}$ & $\% * *$ & Docs.* & Docs.* & Docs.* \\
\hline \multirow{11}{*}{$\begin{array}{l}\text { Inclusive } \\
\text { frame }\end{array}$} & \multirow{5}{*}{ Muslims } & \multirow{5}{*}{$\begin{array}{c}75 \\
(21.4 \%)\end{array}$} & Institutional & 46 & $61.3 \%$ & \multirow{5}{*}{$\begin{array}{c}21 \\
(19.6 \%)\end{array}$} & \multirow{5}{*}{$\begin{array}{c}28 \\
(41.2 \%)\end{array}$} & \multirow{5}{*}{$\begin{array}{c}26 \\
(28.0 \%)\end{array}$} \\
\hline & & & Civil society & 51 & $68.0 \%$ & & & \\
\hline & & & Experts & 15 & $20.0 \%$ & & & \\
\hline & & & Celebrities & 9 & $12.0 \%$ & & & \\
\hline & & & Vox-pop & 38 & $50.7 \%$ & & & \\
\hline & Undefined & $\begin{array}{c}25 \\
(7.1 \%) \\
\end{array}$ & & & & $\begin{array}{c}3 \\
(2.8 \%) \\
\end{array}$ & $\begin{array}{c}9 \\
(13.2 \%) \\
\end{array}$ & $\begin{array}{c}13 \\
(14.0 \%) \\
\end{array}$ \\
\hline & \multirow{5}{*}{$\begin{array}{c}\text { Non- } \\
\text { Muslims }\end{array}$} & \multirow{5}{*}{$\begin{array}{c}106 \\
(30.3 \%)\end{array}$} & Institutional & 81 & $76.4 \%$ & \multirow{5}{*}{$\begin{array}{c}34 \\
(31.8 \%)\end{array}$} & \multirow{5}{*}{$\begin{array}{c}33 \\
(48.5 \%)\end{array}$} & \multirow{5}{*}{$\begin{array}{c}39 \\
(41.9 \%)\end{array}$} \\
\hline & & & Civil society & 47 & $44.3 \%$ & & & \\
\hline & & & Experts & 20 & $18.9 \%$ & & & \\
\hline & & & Celebrities & 13 & $12.3 \%$ & & & \\
\hline & & & Vox-pop & 38 & $35.8 \%$ & & & \\
\hline \multirow{11}{*}{$\begin{array}{l}\text { Neutral } \\
\text { frame }\end{array}$} & \multirow{5}{*}{ Muslims } & \multirow{5}{*}{$\begin{array}{c}92 \\
(26.3 \%)\end{array}$} & Institutional & 56 & $60.9 \%$ & \multirow{5}{*}{$\begin{array}{c}27 \\
(25.2 \%)\end{array}$} & \multirow{5}{*}{$\begin{array}{c}26 \\
(38.2 \%)\end{array}$} & \multirow{5}{*}{$\begin{array}{c}39 \\
(41.9 \%)\end{array}$} \\
\hline & & & Civil society & 60 & $65.2 \%$ & & & \\
\hline & & & Experts & 20 & $21.7 \%$ & & & \\
\hline & & & Celebrities & 11 & $12.0 \%$ & & & \\
\hline & & & Vox-pop & 48 & $52.2 \%$ & & & \\
\hline & Undefined & $\begin{array}{c}37 \\
(10.6 \%) \\
\end{array}$ & & & & $\begin{array}{c}3 \\
(2.8 \%) \\
\end{array}$ & $\begin{array}{c}11 \\
(16.2 \%) \\
\end{array}$ & $\begin{array}{c}23 \\
(24.7 \%) \\
\end{array}$ \\
\hline & \multirow{5}{*}{$\begin{array}{c}\text { Non- } \\
\text { Muslims }\end{array}$} & \multirow{5}{*}{$\begin{array}{c}133 \\
(38.0 \%)\end{array}$} & Institutional & 105 & $78.9 \%$ & \multirow{5}{*}{$\begin{array}{c}43 \\
(40.2 \%)\end{array}$} & \multirow{5}{*}{$\begin{array}{c}42 \\
(61.8 \%)\end{array}$} & \multirow{5}{*}{$\begin{array}{c}48 \\
(51.6 \%)\end{array}$} \\
\hline & & & Civil society & 56 & $42.1 \%$ & & & \\
\hline & & & Experts & 33 & $24.8 \%$ & & & \\
\hline & & & Celebrities & 12 & $9.0 \%$ & & & \\
\hline & & & Vox-pop & 51 & $38.3 \%$ & & & \\
\hline \multirow{11}{*}{$\begin{array}{l}\text { Exclusive } \\
\text { frame }\end{array}$} & \multirow{5}{*}{ Muslims } & \multirow{5}{*}{$\begin{array}{c}76 \\
(21.7 \%)\end{array}$} & Institutional & 49 & $64.5 \%$ & & & \\
\hline & & & Civil society & 41 & $53.9 \%$ & & & \\
\hline & & & Experts & 20 & $26.3 \%$ & 44 & 34 & 01 \\
\hline & & & Celebrities & 11 & $14.5 \%$ & & & \\
\hline & & & Vox-pop & 31 & $40.8 \%$ & & & \\
\hline & Undefined & $\begin{array}{c}23 \\
(6.6 \%)\end{array}$ & & & & $\begin{array}{c}8 \\
(7.5 \%)\end{array}$ & $\begin{array}{c}15 \\
(22.1 \%)\end{array}$ & $\begin{array}{c}26 \\
(28.0 \%)\end{array}$ \\
\hline & & & Institutional & 93 & $69.9 \%$ & & & \\
\hline & & & Civil society & 50 & $37.6 \%$ & & & \\
\hline & Non- & 133 & Experts & 38 & $28.6 \%$ & 54 & 32 & 53 \\
\hline & Muslims & $(38.0 \%)$ & Celebrities & 16 & $12.0 \%$ & $(50.5 \%)$ & $(4 / .1 \%)$ & $(5 / .0 \%)$ \\
\hline & & & Vox-pop & 42 & $31.6 \%$ & & & \\
\hline Heteroge & & 128 & Institutional & 79 & $61.7 \%$ & 34 & 44 & 50 \\
\hline neous & Muslims & $(36.6 \%)$ & Civil society & 78 & $60.9 \%$ & $(31.8 \%)$ & $(64.7 \%)$ & $(53.8 \%)$ \\
\hline
\end{tabular}




\begin{tabular}{|c|c|c|c|c|c|c|c|c|}
\hline \multirow[t]{9}{*}{ frame } & & & Experts & 28 & $21.9 \%$ & & & \\
\hline & & & Celebrities & 15 & $11.7 \%$ & & & \\
\hline & & & Vox-pop & 52 & $40.6 \%$ & & & \\
\hline & Undefined & $\begin{array}{c}37 \\
(10.6 \%)\end{array}$ & & & & $\begin{array}{c}4 \\
(3.7 \%) \\
\end{array}$ & $\begin{array}{c}13 \\
(19.1 \%)\end{array}$ & $\begin{array}{c}20 \\
(21.5 \%) \\
\end{array}$ \\
\hline & \multirow{5}{*}{$\begin{array}{c}\text { Non- } \\
\text { Muslims }\end{array}$} & \multirow{5}{*}{$\begin{array}{c}109 \\
(31.1 \%)\end{array}$} & Institutional & 80 & $73.4 \%$ & \multirow{5}{*}{$\begin{array}{c}34 \\
(31.8 \%)\end{array}$} & \multirow{5}{*}{$\begin{array}{c}36 \\
(52.9 \%)\end{array}$} & \multirow{5}{*}{$\begin{array}{c}39 \\
(41.9 \%)\end{array}$} \\
\hline & & & Civil society & 51 & $46.8 \%$ & & & \\
\hline & & & Experts & 31 & $28.4 \%$ & & & \\
\hline & & & Celebrities & 12 & $11.0 \%$ & & & \\
\hline & & & Vox-pop & 41 & $37.6 \%$ & & & \\
\hline \multirow{11}{*}{$\begin{array}{l}\text { Neutral } \\
\text { frame }\end{array}$} & \multirow{5}{*}{ Muslims } & \multirow{5}{*}{$\begin{array}{c}113 \\
(32.3 \%)\end{array}$} & Institutional & 77 & $68.1 \%$ & \multirow{5}{*}{$\begin{array}{c}31 \\
(29.0 \%)\end{array}$} & \multirow{5}{*}{$\begin{array}{c}40 \\
(58.8 \%)\end{array}$} & \multirow{5}{*}{$\begin{array}{c}42 \\
(45.2 \%)\end{array}$} \\
\hline & & & Civil society & 74 & $65.5 \%$ & & & \\
\hline & & & Experts & 21 & $18.6 \%$ & & & \\
\hline & & & Celebrities & 14 & $12.4 \%$ & & & \\
\hline & & & Vox-pop & 51 & $45.1 \%$ & & & \\
\hline & Undefined & $\begin{array}{c}44 \\
(12.6 \%) \\
\end{array}$ & & & & $\begin{array}{c}5 \\
(4.7 \%) \\
\end{array}$ & $\begin{array}{c}13 \\
(19.1 \%) \\
\end{array}$ & $\begin{array}{c}26 \\
(28.0 \%) \\
\end{array}$ \\
\hline & \multirow{5}{*}{$\begin{array}{l}\text { Non- } \\
\text { Muslims }\end{array}$} & \multirow{5}{*}{$\begin{array}{c}116 \\
(33.1 \%)\end{array}$} & Institutional & 94 & $81.0 \%$ & \multirow{5}{*}{$\begin{array}{c}39 \\
(36.4 \%)\end{array}$} & \multirow{5}{*}{$\begin{array}{c}36 \\
(52.9 \%)\end{array}$} & \multirow{5}{*}{$\begin{array}{c}41 \\
(44.1 \%)\end{array}$} \\
\hline & & & Civil society & 56 & $48.3 \%$ & & & \\
\hline & & & Experts & 28 & $24.1 \%$ & & & \\
\hline & & & Celebrities & 11 & $9.5 \%$ & & & \\
\hline & & & Vox-pop & 44 & $37.9 \%$ & & & \\
\hline \multirow{11}{*}{$\begin{array}{l}\text { Homogen } \\
\text { eous } \\
\text { frame }\end{array}$} & \multirow{5}{*}{ Muslims } & \multirow{5}{*}{$\begin{array}{c}158 \\
(45.1 \%)\end{array}$} & Institutional & 98 & $62.0 \%$ & \multirow{5}{*}{$\begin{array}{c}47 \\
(43.9 \%)\end{array}$} & & \\
\hline & & & Civil society & 86 & $54.4 \%$ & & & \\
\hline & & & Experts & 36 & $22.8 \%$ & & $(662 \%)$ & $(710 \%)$ \\
\hline & & & Celebrities & 24 & $15.2 \%$ & & & \\
\hline & & & Vox-pop & 66 & $41.8 \%$ & & & \\
\hline & Undefined & $\begin{array}{c}53 \\
(15.1 \%) \\
\end{array}$ & & & & $\begin{array}{c}6 \\
(5.6 \%) \\
\end{array}$ & $\begin{array}{c}17 \\
(25.0 \%)\end{array}$ & $\begin{array}{c}30 \\
(32.3 \%) \\
\end{array}$ \\
\hline & & & Institutional & 160 & $74.8 \%$ & & & \\
\hline & & & Civil society & 81 & $37.9 \%$ & & & \\
\hline & Non-- & 214 & Experts & 52 & $24.3 \%$ & 19 & $\begin{array}{c}03 \\
0507\end{array}$ & 100 \\
\hline & & & Celebrities & 24 & $11.2 \%$ & & & \\
\hline & & & Vox-pop & 74 & $34.6 \%$ & & & \\
\hline & & & Institutional & 86 & $62.3 \%$ & & & \\
\hline & & & Civil society & 80 & $58.0 \%$ & & & \\
\hline & Muslims & 138 & Experts & 27 & $19.6 \%$ & 35 & 49 & $\begin{array}{c}54 \\
(50\end{array}$ \\
\hline & & & Celebrities & 22 & $15.9 \%$ & & & \\
\hline & & & Vox-pop & 63 & $45.7 \%$ & & & \\
\hline $\begin{array}{l}\text { Non- } \\
\text { problemat }\end{array}$ & Undefined & $\begin{array}{c}31 \\
(8.9 \%) \\
\end{array}$ & & & & $\begin{array}{c}3 \\
(2.8 \%) \\
\end{array}$ & $\begin{array}{c}18 \\
(26.5 \%) \\
\end{array}$ & $\begin{array}{c}30 \\
(32.3 \%) \\
\end{array}$ \\
\hline & & & Institutional & 131 & $77.5 \%$ & & & \\
\hline & & & Civil society & 70 & $41.4 \%$ & & & \\
\hline & Non- & 169 & Experts & 34 & $20.1 \%$ & $(51+01)$ & $5 /$ & 00 \\
\hline & & & Celebrities & 16 & $9.5 \%$ & & & \\
\hline & & & Vox-pop & 61 & $36.1 \%$ & & & \\
\hline & & & Institutional & 91 & $65.5 \%$ & & & \\
\hline & & & Civil society & 87 & $62.6 \%$ & & & \\
\hline $\begin{array}{l}\text { Neutral } \\
\text { frame }\end{array}$ & Muslims & $\begin{array}{c}139 \\
(307 \%)\end{array}$ & Experts & 32 & $23.0 \%$ & $\begin{array}{c}39 \\
(364 \%)\end{array}$ & $(550 \%)$ & $(6670 \%)$ \\
\hline & & & Celebrities & 17 & $12.2 \%$ & $(30.4 \%)$ & $(55.9 \%)$ & \\
\hline & & & Vox-pop & 56 & $40.3 \%$ & & & \\
\hline
\end{tabular}




\begin{tabular}{|c|c|c|c|c|c|c|c|c|}
\hline & Undefined & $\begin{array}{c}48 \\
(13.7 \%)\end{array}$ & & & & $\begin{array}{c}5 \\
(4.7 \%) \\
\end{array}$ & $\begin{array}{c}14 \\
(20.6 \%)\end{array}$ & $\begin{array}{c}29 \\
(31.2 \%) \\
\end{array}$ \\
\hline & \multirow{5}{*}{$\begin{array}{c}\text { Non- } \\
\text { Muslims }\end{array}$} & \multirow{5}{*}{$\begin{array}{c}143 \\
(40.9 \%)\end{array}$} & Institutional & 109 & $76.2 \%$ & \multirow{5}{*}{$\begin{array}{c}49 \\
(45.8 \%)\end{array}$} & \multirow{5}{*}{$\begin{array}{c}40 \\
(58.8 \%)\end{array}$} & \multirow{5}{*}{$\begin{array}{c}54 \\
(58.1 \%)\end{array}$} \\
\hline & & & Civil society & 65 & $45.5 \%$ & & & \\
\hline & & & Experts & 42 & $29.4 \%$ & & & \\
\hline & & & Celebrities & 18 & $12.6 \%$ & & & \\
\hline & & & Vox-pop & 50 & $35.0 \%$ & & & \\
\hline \multirow{11}{*}{$\begin{array}{l}\text { Problemat } \\
\text { ic frame }\end{array}$} & \multirow{5}{*}{ Muslims } & \multirow{5}{*}{$\begin{array}{c}139 \\
(39.7 \%)\end{array}$} & Institutional & 85 & $61.2 \%$ & \multirow{5}{*}{$\begin{array}{c}44 \\
(41.1 \%)\end{array}$} & \multirow{5}{*}{$\begin{array}{c}34 \\
(50.0 \%)\end{array}$} & \multirow{5}{*}{$\begin{array}{c}61 \\
(65.6 \%)\end{array}$} \\
\hline & & & Civil society & 83 & $59.7 \%$ & & & \\
\hline & & & Experts & 29 & $20.9 \%$ & & & \\
\hline & & & Celebrities & 18 & $12.9 \%$ & & & \\
\hline & & & Vox-pop & 57 & $41.0 \%$ & & & \\
\hline & Undefined & $\begin{array}{c}49 \\
(14.0 \%) \\
\end{array}$ & & & & $\begin{array}{c}8 \\
(7.5 \%)\end{array}$ & $\begin{array}{c}15 \\
(22.1 \%)\end{array}$ & $\begin{array}{c}26 \\
(28.0 \%)\end{array}$ \\
\hline & \multirow{5}{*}{$\begin{array}{c}\text { Non- } \\
\text { Muslims }\end{array}$} & \multirow{5}{*}{$\begin{array}{c}165 \\
(47.1 \%)\end{array}$} & Institutional & 122 & $73.9 \%$ & \multirow{5}{*}{$\begin{array}{c}66 \\
(61.7 \%)\end{array}$} & \multirow{5}{*}{$\begin{array}{c}41 \\
(60.3 \%)\end{array}$} & \multirow{5}{*}{$\begin{array}{c}58 \\
(62.4 \%)\end{array}$} \\
\hline & & & Civil society & 68 & $41.2 \%$ & & & \\
\hline & & & Experts & 46 & $27.9 \%$ & & & \\
\hline & & & Celebrities & 19 & $11.5 \%$ & & & \\
\hline & & & Vox-pop & 56 & $33.9 \%$ & & & \\
\hline Total $* * *$ & & 350 & & & & 107 & 68 & 93 \\
\hline
\end{tabular}

Source: Author.

*In parentheses, percentages with respect to the the total number of documents with voice and source $(\mathrm{V} \& \mathrm{~S})$ records. $* *$ Percentages with respect to the total of documents with corresponding Muslim or non-Muslim V\&S records (third column on the left). Thus, for example, the 46 documents in which Muslim and institutional VyF appear with an inclusive frame account for $61.3 \%$ of the 75 documents with Muslim VyF framed that way.

***Total of documentos with V\&S records.

Once again EP is the most integrative when considering the non-problematic frame, followed by LV, which nevertheless is the most Islamophobic regarding the problematic frame, that is, LV is the newspaper that publishes the highest percentage of documents with V\&S holding a problematising discourse of M\&I. In line with what the data indicate in relation to the dichotomous pairs inclusive/ exclusive and heterogeneous/homogeneous, both ABC and LV present higher percentages in the Islamophobic component of the problematic/non-problematic pair than in the integrative one. On the contrary, EP, with V\&S problematising M\&I in $60 \%$ of the documents, increases the percentage significantly to $84 \%$ of the texts where V\&S frame the Islamic in a non-problematic way.

That there is at least one specific record in a given document does not imply that there are many more. Hence the relevance of also attending to the records themselves as a whole. Table 6 reveals, in line with the above, that EP is the most inclusive newspaper, as well as the least exclusive. It is also the one that mostly projects a heterogeneous image of M\&I. Homogeneous representation predominates in the three media, especially in $\mathrm{ABC}$, which is also the most exclusive daily. Regarding the third dichotomy of frames, $\mathrm{ABC}$ is not only the media outlet that offers the most problematic image of M\&I. It is also the only newspaper that builds its discourse relying more on the V\&S to frame the Islamic in a mostly problematic way. It is worth noting, however, that its non-problematic records reach almost $40 \%$ and that the problematising entries barely exceed $45 \%$. EP is the only one that offers a percentage of non-problematic records higher than $50 \%$ and of problematic ones below $25 \%$. 
Table 6. Islamic Media Framing: Coded Records of Voices and Sources (Year 2017)

\begin{tabular}{|c|c|c|c|c|c|c|c|c|c|c|c|c|}
\hline & \multicolumn{3}{|c|}{3 dailies } & \multicolumn{3}{|c|}{$A b c$} & \multicolumn{3}{|c|}{ El País } & \multicolumn{3}{|c|}{ La Vanguardia } \\
\hline & \multicolumn{2}{|c|}{ Total } & $\%$ & \multicolumn{2}{|c|}{ Total } & $\%$ & \multicolumn{2}{|c|}{ Total } & $\%$ & \multicolumn{2}{|c|}{ Total } & $\%$ \\
\hline Inclusive frame & \multirow{3}{*}{1,696} & 453 & $26.7 \%$ & \multirow{3}{*}{498} & 140 & $28.1 \%$ & \multirow{3}{*}{535} & 172 & $32.1 \%$ & \multirow{3}{*}{663} & 141 & $21.3 \%$ \\
\hline Neutral frame & & 639 & $37.7 \%$ & & 162 & $32.5 \%$ & & 192 & $35.9 \%$ & & 285 & $43.0 \%$ \\
\hline Exclusive frame & & 604 & $35.6 \%$ & & 196 & $39.4 \%$ & & 171 & $32.0 \%$ & & 237 & $35.7 \%$ \\
\hline $\begin{array}{l}\text { Heterogeneous } \\
\text { frame }\end{array}$ & \multirow{3}{*}{2,270} & 638 & $28.1 \%$ & \multirow{3}{*}{648} & 116 & $17.9 \%$ & \multirow{3}{*}{733} & 238 & $32.5 \%$ & \multirow{3}{*}{889} & 284 & $31.9 \%$ \\
\hline Neutral frame & & 447 & $19.7 \%$ & & 136 & $21.0 \%$ & & 143 & $19.5 \%$ & & 168 & $18.9 \%$ \\
\hline $\begin{array}{l}\text { Homogeneous } \\
\text { frame }\end{array}$ & & 1,185 & $52.2 \%$ & & 396 & $61.1 \%$ & & 352 & $48.0 \%$ & & 437 & $49.2 \%$ \\
\hline $\begin{array}{l}\text { Non-problematic } \\
\text { frame }\end{array}$ & \multirow{3}{*}{2,270} & 1,122 & $49.4 \%$ & \multirow{3}{*}{650} & 257 & $39.5 \%$ & \multirow{3}{*}{734} & 428 & $58.3 \%$ & \multirow{3}{*}{886} & 437 & $49.3 \%$ \\
\hline Neutral frame & & 372 & $16.4 \%$ & & 100 & $15.4 \%$ & & 125 & $17.0 \%$ & & 147 & $16.6 \%$ \\
\hline Problematic frame & & 776 & $34.2 \%$ & & 293 & $45.1 \%$ & & 181 & $24.7 \%$ & & 302 & $34.1 \%$ \\
\hline
\end{tabular}

Source: Author.

*Percentages of column and by group of frames. 


\section{The Thematic Agenda of the Islamic and its Framing}

All the countries or sets of them that appear in the press clippings regarding M\&I have been coded. Spain barely represents $20 \%$ of the media coverage throughout the entire year (see Table 7). The percentage rises to less than $70 \%$ if the territorial horizon of 'us' is expanded to the West. $40 \%$ of the texts do not report about other geographic and cultural realities at large, but, to be precise, to Islamised news on international issues unrelated to 'us.' It implies that, even if the newspapers cover other events of Muslim-majority countries or that affect Muslims, no reference is made to their religious identity in reporting. Hence, the coverage of those events is not part of our database.

No significant imbalances are observed between the components of each binary frames. It should be pointed out, nonetheless, that (i) the proportion of exclusive texts is high $(81 \%)$ only when it comes to news about the non-Western world; (ii) the homogenising frame predominates in the coverage about Spain and the West, and (iii) Spain and the West are framed to a greater extent in the non-problematic way, while the problematising and non-problematising coverage of M\&I is balanced when addressing non-Western territories. Finally, it is significant the scarce presence of exclusive texts when dealing with Spanish news, and, secondly, that almost $45 \%$ of the records of such dichotomous frames respond to a third one, i.e., the neutral frame. Thus, when reporting about people because of their Muslimness, they are not rejected as strangers, but neither are they included as members of 'us.'

Table 7 also includes the topics of media coverage. The topics covered in more news (between 15\% and 19\% of the total) are those related to religious clothing, those which explicitly consider Islam relationship vis-à-vis 'us,' and those referred to both the violence of 'them' and the violence against 'them.' The texts on Islam as a religion in general, on women in Islam, on mosques and imams, on President Trump, on elections, and explicitly referring to Islamophobia are also above the median. Together, texts on the violence against Muslims and texts explicitly alluding to Islamophobia account for $25.5 \%$ of the 432 units of analysis.

A greater predominance of the Islamophobic frames is observed in considering the topics one by one. Once again, however, the press does not problematise M\&I: the non-problematic frame is superior to the problematic one in half of the topics in most of them, by more than 20 percentage points, higher in the case of news about Islamophobia and in which, without using such a term, some form of violence suffered by people for being Muslims is reported. M\&I are portrayed as problematic especially in the news on cultural issues.

Considering that we codify the core theme or themes of each document, only $\mathrm{ABC}$ and LV get to devote more than $20 \%$ of their texts to a given topic - the violence of Muslims. In combining the documents about the violence that Muslins suffer and the documents that explicitly allude to Islamophobia, the three newspapers address the topic in more than $20 \%$ of their coverage, although EP is the only one that does it in more than $30 \%$ of its coverage $(n=44)$. 
None of the newspapers biases its coverage by adopting a unique frame (see Table 8), not even on whether the Muslims are part of 'us' or not. That is not against the evidence that the exclusive and the homogenising frames predominate, both of them slightly more so in ABC than in EP and LV. The most significant differences among the three newspapers are seen again on whether M\&I entail a problem or not. On the one hand, it is the dilemma in which the media expose the public to an imprecise image (neutral frame) to a lesser extent. On the other hand, $\mathrm{EP}$ is the daily with the least problematic coverage. It is also the one that frames in a non-problematic way to the largest extent, both in its full coverage and when covers the topics to which it pays more attention. There are only two topics that covers with a problematic frame in more documents than the corresponding median: the violence of them $(n=10)$ and the elections $(n=8)$.

There are fewer differences between $\mathrm{ABC}$ and LV than with EP, although a somewhat more Islamophobic coverage is observed in the first one. For example, if both dailies opt for the problematic frame of Muslim women and clothing, LV matches with EP in considering the relationship between Islam and 'us' in a largely non-problematic way, and balances its coverage of mosques and imams between the problematic frame - to which $\mathrm{ABC}$ tends - and the non-problematic one. In line with these results, $\mathrm{ABC}$ transmits to its readers a negative image of M\&I regardless of whether news are relative to Spain, extend to the West or refer to the rest of territories. EP mostly frames M\&I as non-problematic regardless of the territory at stake, resulting LV in an intermediate position (see Table 8).

The attacks in Barcelona and Cambrils do not appear as a topic because the news about terrorism have been excluded in this study. However, the press addressed collateral issues to both the perpetration of the August crimes and the consequent state response. In fact, we noted above that, taken together, such issues received the most media attention. No other topic has deserved so much coverage in a concentrated space of time and by the three newspapers in unison. Between August 18 (the day after the attacks in Barcelona city) and September 5, 37 out of the 51 news in our database were related to the attacks. In line with what might be expected from the reaction of the Western press to jihadist attacks, ABC $(n=6)$ adopted a mostly exclusive, homogeneous and problematic frame in a greater percentage of texts during those days than in the seven and a half previous months. On the contrary, LV $(n=15)$ turned from largely exclusive and problematic framing to portray M\&I primarily in an inclusive and non-problematic way, although in percentages slightly lower than EP $(n=16) .{ }^{22}$ Finally, ABC reduced the percentage of pieces with problematic frame after the period of coverage of the attacks (from $64 \%$ to $45 \%$ ), just three points above the pieces framing M\&I in a non-problematic manner. Both EP (over 50\%) and LV continued to favour the non-problematic framing of the Islamic.

\footnotetext{
${ }^{22} \mathrm{EP}$ increased the amount of documents with such frames by 13 and 10 percentage points, respectively.
} 
Table 7. Islamic Media Framing: Proportion of Documents Coded by Topics and Territories (Abc, El País and La Vanguardia. 2017)*

\begin{tabular}{|c|c|c|c|c|c|c|c|c|c|c|c|c|}
\hline & & \multicolumn{2}{|c|}{ Records } & \multirow{2}{*}{$\begin{array}{l}\text { Inclusive } \\
\text { frame }\end{array}$} & \multirow{2}{*}{$\begin{array}{l}\text { Neutral } \\
\text { frame }\end{array}$} & \multirow{2}{*}{$\begin{array}{l}\text { Exclusive } \\
\text { frame }\end{array}$} & \multirow{2}{*}{$\begin{array}{l}\text { Heterogeneous } \\
\text { frame }\end{array}$} & \multirow{2}{*}{$\begin{array}{l}\text { Neutral } \\
\text { frame }\end{array}$} & \multirow{2}{*}{$\begin{array}{c}\text { Homogeneous } \\
\text { frame }\end{array}$} & \multirow{2}{*}{$\begin{array}{l}\text { Non- } \\
\text { problematic } \\
\text { frame }\end{array}$} & \multirow{2}{*}{$\begin{array}{l}\text { Neutral } \\
\text { frame }\end{array}$} & \multirow{2}{*}{$\begin{array}{l}\text { Problematic } \\
\text { frame }\end{array}$} \\
\hline & & Total & $\% * *$ & & & & & & & & & \\
\hline \multirow{21}{*}{ Topics } & Islam (religion) & 39 & $9.0 \%$ & $16.7 \%$ & $30.0 \%$ & $53.3 \%$ & $43.6 \%$ & $0.0 \%$ & $56.4 \%$ & $34.1 \%$ & $17.1 \%$ & $48.8 \%$ \\
\hline & $\begin{array}{l}\text { Interreligious } \\
\text { dialogue (with } \\
\text { Islam) }\end{array}$ & 23 & $5.3 \%$ & $11.1 \%$ & $16.7 \%$ & $72.2 \%$ & $39.1 \%$ & $8.7 \%$ & $52.2 \%$ & $45.8 \%$ & $29.2 \%$ & $25.0 \%$ \\
\hline & Islam vs. 'us' & 68 & $15.7 \%$ & $26.6 \%$ & $14.1 \%$ & $59.4 \%$ & $29.0 \%$ & $1.4 \%$ & $69.6 \%$ & $31.5 \%$ & $12.3 \%$ & $56.2 \%$ \\
\hline & Woman & 48 & $11.1 \%$ & $35.7 \%$ & $35.7 \%$ & $28.6 \%$ & $39.6 \%$ & $12.5 \%$ & $47.9 \%$ & $29.6 \%$ & $14.8 \%$ & $55.6 \%$ \\
\hline & Clothing & 70 & $16.2 \%$ & $23.2 \%$ & $51.8 \%$ & $25.0 \%$ & $22.9 \%$ & $35.7 \%$ & $41.4 \%$ & $38.3 \%$ & $13.6 \%$ & $48.1 \%$ \\
\hline & Family & 14 & $3.2 \%$ & $100.0 \%$ & $0.0 \%$ & $0.0 \%$ & $57.1 \%$ & $0.0 \%$ & $42.9 \%$ & $31.3 \%$ & $18.8 \%$ & $50.0 \%$ \\
\hline & Public moral & 27 & $6.3 \%$ & $60.0 \%$ & $40.0 \%$ & $0.0 \%$ & $48.1 \%$ & $14.8 \%$ & $37.0 \%$ & $14.3 \%$ & $7.1 \%$ & $78.6 \%$ \\
\hline & $\begin{array}{l}\text { Other religious } \\
\text { or cultural } \\
\text { practices }\end{array}$ & 8 & $1.9 \%$ & $40.0 \%$ & $0.0 \%$ & $60.0 \%$ & $0.0 \%$ & $0.0 \%$ & $100.0 \%$ & $37.5 \%$ & $0.0 \%$ & $62.5 \%$ \\
\hline & $\begin{array}{l}\text { Freedom of } \\
\text { expression }\end{array}$ & 2 & $0.5 \%$ & $0.0 \%$ & $100.0 \%$ & $0.0 \%$ & $0.0 \%$ & $0.0 \%$ & $100.0 \%$ & $50.0 \%$ & $50.0 \%$ & $0.0 \%$ \\
\hline & $\begin{array}{l}\text { Mosques and/or } \\
\text { imams }\end{array}$ & 55 & $12.7 \%$ & $40.4 \%$ & $36.2 \%$ & $23.4 \%$ & $32.7 \%$ & $14.5 \%$ & $52.7 \%$ & $43.3 \%$ & $23.3 \%$ & $33.3 \%$ \\
\hline & $\begin{array}{l}\text { Mosque of } \\
\text { Cordoba }\end{array}$ & 6 & $1.4 \%$ & $0.0 \%$ & $33.3 \%$ & $66.7 \%$ & $0.0 \%$ & $16.7 \%$ & $83.3 \%$ & $0.0 \%$ & $33.3 \%$ & $66.7 \%$ \\
\hline & Laicism & 4 & $0.9 \%$ & $0.0 \%$ & $75.0 \%$ & $25.0 \%$ & $25.0 \%$ & $25.0 \%$ & $50.0 \%$ & $0.0 \%$ & $0.0 \%$ & $100.0 \%$ \\
\hline & Islamophobia & 44 & $10.2 \%$ & $28.6 \%$ & $47.6 \%$ & $23.8 \%$ & $15.9 \%$ & $6.8 \%$ & $77.3 \%$ & $84.8 \%$ & $6.5 \%$ & $8.7 \%$ \\
\hline & $\begin{array}{l}\text { Violence against } \\
\text { them }\end{array}$ & 66 & $15.3 \%$ & $33.3 \%$ & $12.5 \%$ & $54.2 \%$ & $29.2 \%$ & $3.1 \%$ & $67.7 \%$ & $76.1 \%$ & $10.4 \%$ & $13.4 \%$ \\
\hline & Violence of them & 84 & $19.4 \%$ & $17.2 \%$ & $35.9 \%$ & $46.9 \%$ & $46.4 \%$ & $8.3 \%$ & $45.2 \%$ & $23.7 \%$ & $8.6 \%$ & $67.7 \%$ \\
\hline & Trump & 36 & $8.3 \%$ & $8.3 \%$ & $13.9 \%$ & $77.8 \%$ & $25.0 \%$ & $0.0 \%$ & $75.0 \%$ & $58.3 \%$ & $13.9 \%$ & $27.8 \%$ \\
\hline & Pontifical visits & 26 & $6.0 \%$ & $5.3 \%$ & $5.3 \%$ & $89.5 \%$ & $53.8 \%$ & $11.5 \%$ & $34.6 \%$ & $42.9 \%$ & $21.4 \%$ & $35.7 \%$ \\
\hline & Elections & 42 & $9.7 \%$ & $39.4 \%$ & $18.2 \%$ & $42.4 \%$ & $23.8 \%$ & $2.4 \%$ & $73.8 \%$ & $44.4 \%$ & $17.8 \%$ & $37.8 \%$ \\
\hline & Sport & 11 & $2.5 \%$ & $20.0 \%$ & $30.0 \%$ & $50.0 \%$ & $9.1 \%$ & $27.3 \%$ & $63.6 \%$ & $63.6 \%$ & $0.0 \%$ & $36.4 \%$ \\
\hline & Refugees & 15 & $3.5 \%$ & $0.0 \%$ & $13.3 \%$ & $86.7 \%$ & $0.0 \%$ & $13.3 \%$ & $86.7 \%$ & $53.3 \%$ & $20.0 \%$ & $26.7 \%$ \\
\hline & Other & 19 & $4.4 \%$ & $25.0 \%$ & $62.5 \%$ & $12.5 \%$ & $31.6 \%$ & $21.1 \%$ & $47.4 \%$ & $60.0 \%$ & $25.0 \%$ & $15.0 \%$ \\
\hline \multirow[b]{3}{*}{ Territories } & Spain & 88 & $20.4 \%$ & $30.0 \%$ & $42.2 \%$ & $27.8 \%$ & $19.3 \%$ & $19.3 \%$ & $61.4 \%$ & $45.3 \%$ & $17.9 \%$ & $36.8 \%$ \\
\hline & The West*** & 297 & $68.8 \%$ & $26.5 \%$ & $36.0 \%$ & $37.5 \%$ & $19.3 \%$ & $13.1 \%$ & $67.6 \%$ & $47.1 \%$ & $14.4 \%$ & $38.6 \%$ \\
\hline & $\begin{array}{l}\text { Non-Western } \\
\text { countries and } \\
\text { territories } * * * *\end{array}$ & 172 & $39.8 \%$ & $4.1 \%$ & $15.1 \%$ & $80.8 \%$ & $47.2 \%$ & $8.8 \%$ & $44.0 \%$ & $36.9 \%$ & $18.2 \%$ & $44.8 \%$ \\
\hline
\end{tabular}

Source: Author.

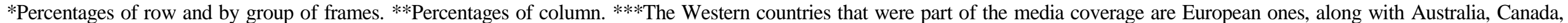
Israel, New Zealand, and the USA. References to Europe and the West themselves, as well as to the European Union and the Christian world are also coded as 'the West.'

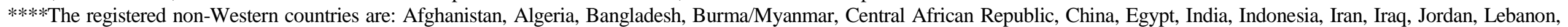

Malaysia, Morocco, Oman, Pakistan, Palestine, Qatar, Saudi Arabia, Singapore, Syria, Tunisia and Turkey. The explicit references to the "Islamic world" are also counted. 
Table 8. Islamic Media Framing: Documents Coded by Either Topic or Territory and by Newspaper (Year 2017)*

\begin{tabular}{|c|c|c|c|c|c|c|c|c|c|c|}
\hline & \multirow[t]{2}{*}{$\begin{array}{l}\text { Inclusive } \\
\text { frame }\end{array}$} & \multirow{2}{*}{$\begin{array}{c}\text { Neutral frame } \\
\mathbf{L V}(\rightarrow \mathbf{9})\end{array}$} & \multirow{2}{*}{$\begin{array}{c}\begin{array}{c}\text { Exclusive } \\
\text { frame }\end{array} \\
\text { ABC (58) } \\
\text { EP (29) } \\
\end{array}$} & \multirow{2}{*}{$\begin{array}{c}\begin{array}{c}\text { Heterogeneous } \\
\text { frame }\end{array} \\
\text { EP }(40)\end{array}$} & \multirow[t]{2}{*}{$\begin{array}{c}\text { Neutral } \\
\text { frame }\end{array}$} & \multirow{2}{*}{$\begin{array}{c}\text { Homogeneous } \\
\text { frame }\end{array}$} & \multirow{2}{*}{$\begin{array}{c}\begin{array}{c}\text { Non-problematic } \\
\text { frame }\end{array} \\
\text { EP }(10)\end{array}$} & \multirow[t]{2}{*}{$\begin{array}{c}\text { Neutral } \\
\text { frame }\end{array}$} & \multirow{2}{*}{$\begin{array}{c}\begin{array}{c}\text { Problematic } \\
\text { frame }\end{array} \\
\text { ABC (33) } \\
\text { LV (12.5) }\end{array}$} \\
\hline \multirow{15}{*}{ Topics } & Islam (religion) & & & & & & & & & \\
\hline & $\begin{array}{l}\text { Interreligious dialogue (with } \\
\text { Islam) }\end{array}$ & & & $\begin{array}{l}\mathrm{ABC}(83) \\
\mathrm{EP}(100) \\
\mathbf{L V}(\mathbf{4 0})\end{array}$ & $\begin{array}{c}\mathrm{ABC}(12.5) \\
\mathrm{EP}(=)^{* *}\end{array}$ & $\mathrm{EP}(=) * *$ & $\begin{array}{l}\mathrm{EP}(=)^{* *} \\
\mathbf{L V}(\mathbf{3 3})\end{array}$ & \begin{tabular}{|c|}
$\mathrm{ABC}(37.5)$ \\
$\mathrm{EP}(67)$ \\
$\mathbf{L V}((\mathbf{3 8 . 5 \% )}) * * *$ \\
\end{tabular} & & $\begin{array}{c}\mathbf{L V} \\
((38.5 \%))^{* * * *}\end{array}$ \\
\hline & Islam vs. 'us' & & & $\begin{array}{c}\mathrm{ABC}(76) \\
\operatorname{EP}(6) \\
\operatorname{LV}(5) \\
\end{array}$ & & & $\begin{array}{l}\text { ABC (70) } \\
\text { EP (35) } \\
\operatorname{LV~(9)} \\
\end{array}$ & $\begin{array}{l}\text { EP (9.5) } \\
\operatorname{LV}(\mathbf{4})\end{array}$ & & $\mathrm{ABC}(75)$ \\
\hline & Woman & LV (10) & $(\leftarrow 33) \mathbf{E P}$ & $\mathrm{ABC}(22)$ & $\begin{array}{c}\text { EP (23) } \\
\operatorname{LV}((\mathbf{4 8 \%}))\end{array}$ & & $\begin{array}{c}\text { ABC (50) } \\
\operatorname{LV}((48 \%))\end{array}$ & EP (13) & & $\begin{array}{c}\operatorname{ABC}(60) \\
\text { LV (29) }\end{array}$ \\
\hline & Clothing & & $\begin{array}{l}\text { ABC } \\
\text { EP } \\
\text { LV }\end{array}$ & & LV ((39\%)) & $\begin{array}{c}\mathbf{E P}(\rightarrow \mathbf{6}) \\
\mathbf{L V} \\
((39 \%)) \\
\end{array}$ & $\mathrm{ABC}(\mathbf{5 0})$ & EP (21) & & $\begin{array}{l}\mathrm{ABC}(31) \\
\operatorname{LV}(4)\end{array}$ \\
\hline & Family & LV (100) & & & $\begin{array}{l}\mathrm{ABC}(100) \\
\mathrm{EP}(100)\end{array}$ & & LV (33) & & & $\begin{array}{l}\text { ABC (100) } \\
\text { EP (20) } \\
\text { LV (10) } \\
\end{array}$ \\
\hline & Public moral & $\begin{array}{l}\text { EP (100) } \\
\text { LV (100) }\end{array}$ & $\mathrm{ABC}$ & & $\begin{array}{l}\mathrm{ABC}(33) \\
\mathrm{EP}(14)\end{array}$ & & LV (9) & & & $\begin{array}{l}\mathrm{ABC}(67) \\
\mathrm{EP}(75) \\
\mathrm{LV}(54) \\
\end{array}$ \\
\hline & $\begin{array}{l}\text { Other religious or cultural } \\
\text { practices }\end{array}$ & $\mathrm{ABC}(100)$ & & $\begin{array}{l}\text { EP (33) } \\
\operatorname{LV}(100)\end{array}$ & & & $\begin{array}{l}\mathrm{ABC}(100) \\
\mathrm{EP}(100) \\
\mathrm{LV}(100)\end{array}$ & $\mathrm{ABC}(100)$ & & $\begin{array}{c}\text { EP (20) } \\
\text { LV (100) }\end{array}$ \\
\hline & Freedom of expression & & EP & & & & $\mathrm{EP}(100)$ & EP (50) & & \\
\hline & Mosques and/or imams & $\begin{array}{l}\operatorname{ABC}(6) \\
\operatorname{EP}(26)\end{array}$ & $(\leftarrow 9) \mathrm{LV}$ & & & & $\begin{array}{c}\text { ABC (29) } \\
\text { EP (9) } \\
\text { LV (19) }\end{array}$ & $\begin{array}{c}\text { EP (36) } \\
\operatorname{LV}((42.9 \%))\end{array}$ & & $\begin{array}{c}\mathrm{ABC}(12) \\
\operatorname{LV}((42.9 \%))\end{array}$ \\
\hline & Mosque of Cordoba & & LV & $\mathrm{ABC}(80)$ & & & $\begin{array}{l}\mathrm{ABC}(80) \\
\mathrm{LV}(100)\end{array}$ & & LV & $\mathrm{ABC}(80)$ \\
\hline & Laicism & & $\begin{array}{c}\mathrm{ABC}(\rightarrow 22) \\
\mathrm{LV}\end{array}$ & & $\mathrm{ABC}(=)$ & $\mathrm{ABC}(=)$ & $\begin{array}{l}\mathrm{ABC}(=) \\
\mathrm{LV}(100)\end{array}$ & & & $\begin{array}{l}\text { ABC (100) } \\
\text { LV (100) }\end{array}$ \\
\hline & Islamophobia & & $\begin{array}{c}(\leftarrow 17) \mathrm{ABC} \\
\mathbf{E P} \\
\mathbf{L V} \\
\end{array}$ & & & & $\begin{array}{c}\mathrm{ABC}(100) \\
\text { EP (70) } \\
\text { LV (65) }\end{array}$ & $\begin{array}{l}\mathrm{ABC}(86) \\
\text { EP (85) } \\
\text { LV (63) }\end{array}$ & & \\
\hline & Violence against them & & $(\leftarrow 37.5) \mathrm{ABC}$ & $\begin{array}{l}\text { EP (47) } \\
\text { LV (33) }\end{array}$ & & & $\begin{array}{c}\mathrm{ABC}(46) \\
\mathrm{EP}(17) \\
\mathrm{LV}(80)\end{array}$ & $\begin{array}{c}\mathrm{ABC}(56) \\
\mathrm{EP}(71) \\
\mathrm{LV}(62.5)\end{array}$ & & \\
\hline & Violence of them & & LV & $\mathrm{ABC}(46)$ & LV (30) & & $\mathrm{ABC}(25)$ & & & $\mathrm{ABC}(74)$ \\
\hline
\end{tabular}




\begin{tabular}{|c|c|c|c|c|c|c|c|c|c|}
\hline & & & & EP (54) & & EP (5) & & & $\begin{array}{l}\text { EP (21) } \\
\text { LV (28) }\end{array}$ \\
\hline & Trump & & & $\begin{array}{c}\mathrm{ABC}(90) \\
\text { EP (67) } \\
\text { LV (57) }\end{array}$ & & $\begin{array}{c}\mathrm{ABC}(60) \\
\mathrm{EP}(50) \\
\operatorname{LV}(43)\end{array}$ & $\begin{array}{l}\text { EP (58) } \\
\text { LV (50) }\end{array}$ & & $\mathrm{ABC}(30)$ \\
\hline & Pontifical visits & & & $\begin{array}{c}\mathbf{A B C}(\mathbf{9 2}) \\
\mathrm{EP}(100) \\
\text { LV (60) }\end{array}$ & $\begin{array}{c}\mathbf{A B C}(\mathbf{1 2}) \\
\text { EP (50) } \\
\text { LV (20) }\end{array}$ & & $\begin{array}{c}\mathbf{A B C}(\mathbf{1 1}) \\
\mathrm{EP}(25)\end{array}$ & & LV (17) \\
\hline & Elections & $\begin{array}{c}\mathbf{E P}(\mathbf{8}) \\
\text { LV (25) }\end{array}$ & & ABC (19) & & $\begin{array}{c}\mathbf{A B C}(\mathbf{8 7 . 5}) \\
\mathbf{E P}(\mathbf{4 0}) \\
\operatorname{LV}(9) \\
\end{array}$ & $\mathrm{ABC}(28)$ & & $\begin{array}{l}\mathbf{E P}(\mathbf{6}) \\
\operatorname{LV}(9)\end{array}$ \\
\hline & Sport & & $\mathrm{LV}(\rightarrow 17)$ & $\begin{array}{l}\mathrm{ABC}(33) \\
\mathrm{EP}(100)\end{array}$ & & $\begin{array}{c}\mathrm{ABC}(100) \\
\mathrm{EP}(100) \\
\mathrm{LV}(50)\end{array}$ & $\begin{array}{c}\mathrm{ABC}(33) \\
\mathrm{EP}((50 \%)) \\
\mathrm{LV}(33)\end{array}$ & & $\mathrm{EP}((50 \%))$ \\
\hline & Refugees & & & $\begin{array}{c}\text { ABC (100) } \\
\text { EP (83) } \\
\text { LV (80) }\end{array}$ & & $\begin{array}{c}\mathrm{ABC}(100) \\
\mathrm{EP}(83) \\
\mathrm{LV}(80)\end{array}$ & $\begin{array}{l}\text { EP (33) } \\
\text { LV (40) }\end{array}$ & $\mathrm{ABC}$ & \\
\hline & Other & $\mathrm{ABC}(100)$ & $\begin{array}{l}\mathrm{EP}(\rightarrow 33) \\
(\leftarrow 50) \mathrm{LV}\end{array}$ & & EP (43) & $\begin{array}{l}\mathrm{ABC}(100) \\
\mathrm{LV}(40)\end{array}$ & $\begin{array}{c}\mathrm{ABC}(100) \\
\mathrm{EP}(71) \\
\mathrm{LV}(18)\end{array}$ & & \\
\hline & Spain & $\mathrm{EP}((35 \%))$ & $\begin{array}{c}\mathrm{ABC}(\rightarrow 5) \\
\mathrm{EP}((35 \%)) \\
(4 \leftarrow) \mathrm{LV}\end{array}$ & & & $\begin{array}{c}\mathrm{ABC}(67) \\
\mathrm{EP}(26) \\
\mathrm{LV}(19) \\
\end{array}$ & $\begin{array}{l}\text { EP (74) } \\
\text { LV (27) }\end{array}$ & & $\mathrm{ABC}(40.5)$ \\
\hline Territories & The West $* * * * *$ & & $\begin{array}{c}(8 \leftarrow) \mathrm{EP}(\rightarrow 8) \\
\mathrm{LV}(\rightarrow 13)\end{array}$ & $\mathrm{ABC}(25)$ & & $\begin{array}{c}\mathrm{ABC}(67) \\
\mathrm{EP}(38) \\
\mathrm{LV}(34)\end{array}$ & $\begin{array}{l}\text { EP (39) } \\
\text { LV (21) }\end{array}$ & & $\mathrm{ABC}(24)$ \\
\hline & $\begin{array}{l}\text { Non-Western countries and } \\
\text { territories**** }\end{array}$ & & & $\begin{array}{c}\mathrm{ABC}(96) \\
\mathrm{EP}(68) \\
\mathrm{LV}(62.5)\end{array}$ & EP (53) & $\begin{array}{l}\mathrm{ABC}(10) \\
\mathrm{LV}(1)\end{array}$ & EP (19) & & $\begin{array}{l}\mathrm{ABC}(20) \\
\mathrm{LV}(20)\end{array}$ \\
\hline
\end{tabular}

\section{Source: Author.}

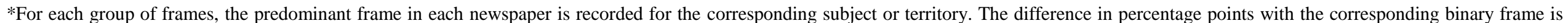

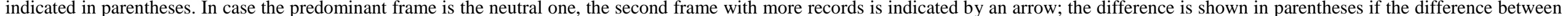

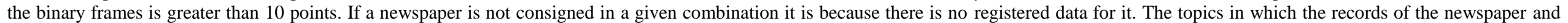
topic at stake are above the median of that newspaper by topics are highlighted in bold.

**The equal sign in parentheses indicates that the records are evenly distributed among the three variants of a given group of frames, neutral one included

***The percentages that coincide between two variants of a given group of frames are shown inside double parentheses.

$* * * *$ See table 4. 


\section{Conclusions}

It is not strange to encounter the question of why a xenophobic organization has not gained parliamentary strength in Spain, contrary to the success of them in a large part of Europe (Alonso and Rovira 2015). ${ }^{23}$ As to the rejection of M\&I, opinion polls show that this is a less widespread attitude in Spain than among its counterparts. A recent Pew survey (2018) indicates, e.g., that it is the sixth European country (and the first among the Mediterranean ones), with more people saying (74\%) that they would accept Muslims in their family (see also Dennison and Dražanová 2018). One contributing factor in the receptive attitude of Spaniards towards those who profess Islam could be mass media. Our analysis of the Spanish media discourse supports the hypothesis.

We have analysed whether the opinion and the attitude that the press tends to shape is Islamophobic or integrative. For this we have attended to the extent to which it opts, respectively, for the exclusive vs. inclusive, homogenising vs. heterogenising, and problematising or not of M\&I. It has been done taking into consideration both the total coverage records and the documents in which these records appear in relation to the categories 'subject' - references to the Islamic subject - and 'voices and sources' - which the media use to shape the image of reality in reporting. The third category analysed was the news topics, which have been coded as a unique record per document.

The empirical evidence shows that there is no incitement to violent action against Muslims; it is not a racist media discourse directed against the Muslim 'other.' An image of rejection of the Islamic is projected, nonetheless, to the point of being possible to read definitions of the hijab as a "castrator veil" 24 and of Islam as an "ideology of imposition" 25 as well as categorical statements such as "they do not try to integrate themselves into Spanish society." 26 In fact, most 'subject' records see Muslims as a stranger or outsider (exclusive frame) belonging to a community of undifferentiated peers (homogeneous frame). As a result, there is a racist discourse about the Islamised 'other.' However, if on the one hand the different integrative frames suppose at least a quarter of the coverage, the non-problematic one equals the problematic one. In the case of $\mathrm{V} \& S$, the presence of the former is even larger.

To sum up, the Spanish media coverage is more homogenising than exclusive, although it presents both Islamophobic traits. On the other hand, it is more balanced in its framing of M\&I as a problem, and in fact it tends to portrays the Islamic as non-problematic. The democratic principle of pluralism of information is translated, in any case, into a plurality of frames. Thus, while the $\mathrm{H} 2$ is confirmed, the $\mathrm{H} 1$ is qualified. This is all the more so because the diversity of frames is accompanied by a plurality of V\&S: both institutional and non-

\footnotetext{
${ }^{23}$ This study was conducted and concluded prior to the 2018 Andalusian elections, as a result of which Vox, a far-right formation, won 12 seats in the regional Parliament, and prior to the 2019 general elections ( 24 seats). In the absence of due research, the media coverage of the candidacy seems to have focused on issues other than its Islamophobic discourse.

${ }^{24} \mathrm{ABC}, 22-5-17$, p.76.

${ }^{25} \mathrm{LV}, 18-3-17$, p.23.

${ }^{26} \mathrm{ABC}, 27-8-17$, p.3.
} 
institutional, and both Muslim and non-Muslim. In this regard, it can be concluded, on the one hand, that there is no silencing or exclusion of either Muslim or extrainstitutional V\&S. On the other, that, even though both institutional and nonMuslim V\&S predominate, and even though they are mostly framed Islamophobically, it occurs again with the exception of the problematic frame.

$\mathrm{H} 3$ and $\mathrm{H} 4$ are also confirmed: centrist LV appears less integrative than leftist $\mathrm{EP}$, but more so than right-wing $\mathrm{ABC}$, from which it can be inferred that, being ideology important, territoriality is not a relevant factor to explain framing of M\&I. Regarding EP it is worth adding that it is also the newspaper that Islamises contents to the lesser extent, both by the number of published news and by the total amount of words of its coverage, but also by the volume of opinion entries. Even though LV and ABC publish more news than EP, what is published by each of them is reduced to less than one third of the days of the year - less than a quarter in the case of $\mathrm{ABC}$ and $\mathrm{EP}$. In the absence of comparative elements with other media systems, it allows to deduce, perhaps not disinterest in M\&I issues, but willingness not to Islamise the public agenda. The hypothesis would be supported by the low percentage of news specifically related to the Spanish reality. It remains open for future research.

The analysis of the media topics corroborates the conclusions reached so far and allows to validate H5. The news published in the context of the attacks of August have been particularly enlightening: at a critical juncture, for it was susceptible to racist reactions (Islamophobic on this occasion), both EP and LV opted for reducing the presence of the Islamophobic frames and for increasing the integrative ones in addressing the multiple aspects they covered vis-à-vis their previous coverage of M\&I. ABC opted for a more Islamophobic discourse than the one it was holding so far. At the same time, nonetheless, the right-wing daily reduced its coverage to less than half the number of pieces of the other two newspapers; that is, it became more Islamophobic while, potentially neutralising its social and political impact, Islamised to a lesser extent.

Taking together the diversity of frames and the differences pointed out among the newspapers, the Spanish press projects a rather homogeneous image of M\&I and tends to shape it as a strange 'other,' explicitly or implicitly excluded from 'us.' It would not be contributing, therefore, to the inclusion of Muslims as a perceived part of an actually pluralistic or multicultural society. But neither can be said of the media discourse that is fuelling fears, tensions or hostilities towards M\&I. More often than not, the Islamic dimension of reality appears as an issue that is avoided, firstly, in avoiding the Islamisation of subjects and topics and, secondly, by the relevant presence of the neutral frame in Islamised coverage. This kind of silence could help to understand the absence of rejection by Spanish public opinion, the Bourdieu's 'habitus' that would be contributing to shape, but such a silence could also be implying an absence of knowledge of the equal 'other' with which 'we' live more and more on this side of the Mediterranean. 


\section{References}

Ahmed S, Matthes J (2016) Media representation of Muslims and Islam from 2000 to 2015. International Communication Gazette 79(3): 219-244.

Alba S (2015) Islamofobia. Barcelona: Icaria.

Alonso S, Rovira C (2015) Spain: No country for the populist radical right? South European Society and Politics 20(1): 21-45.

Ameli S, Merali A (2015) Environment of Hate: The New Normal for Muslims in the UK. Wembley: IHRC.

Anderson L (2015) Countering Islamophobic media representations: The potential role of peace journalism. Global Media and Communication 11(3): 255-270.

Ash TG (2017) It's the kultur, stupid. New York Rev. Books, December 7. Retrieved from https://www.nybooks.com/articles/2017/12/07/germany-alt-right-kultur-stupid. [Accessed 18 September 2019)].

Baker P, Gabrielatos C, McEnery T (2013a) Sketching Muslims: A corpus driven analysis of representations around the word 'Muslim' in the British press 1998-2009. Applied Linguistics 34(3): 255-278.

Baker P, Gabrielatos C, McEnery T (2013b) Discourse Analysis and Media Attitudes: The Representation of Islam in the British Press. Cambridge: Cambridge University Press.

Bauman Z (2016) Strangers at Our Door. Cambridge: Polity Press.

Berbers A, Joris W, Boesman J, D’Haenens L, Koeman J, Van Gorp B (2016) The news framing of the 'Syria fighters' in Flanders and the Netherlands: Victims or terrorists? Ethnicities 16(6): 798-818.

Bourdieu P (1994) Raisons Pratiques. Paris: Éditions du Seuil.

Bowe B, Makki T (2016) Muslim neighbors or an Islamic threat? A constructionist analysis of newspaper coverage of mosque controversies. Media Culture and Society 38(4): 540-558.

Bowe B, Fahmy S, Matthes J (2015) U.S. newspapers provide nuanced picture of Islam. Newspaper Research Journal 36(1): 42-57.

Brown MD (2006) Comparative analysis of mainstream discourses, media narratives and representations of Islam in Britain and France prior to 9/11. Journal of Muslim Minority Affairs 26(3): 297-312.

Butler-Sloss E, Kessler E (2015) Living with Difference: Community, Diversity and the Common Good. Cambridge: The Woolf Institute.

Cebolla H, González-Ferrer A (2008. La Inmigración en España (2000-2007). Madrid: CEPC.

Chouliaraki L (2013) Re-mediation, inter-mediation, trans-mediation. Journalism Studies 14(2): 267-283.

Chouliaraki L, Zaborowski R (2017) Voice and community in the 2015 refugee crisis: A content analysis of news coverage in eight European countries. International Communication Gazette 79(6-7): 613-635.

Corm G (2004) La Fractura Imaginaria. Barcelona: Tusquets.

Corral A (2014) Islamofobia en la prensa digital? Análisis de los comentarios en 'La inocencia de los musulmanes.' In F Sabés, J Verón (eds) Universidad, Investigación y Periodismo Digital. Zaragoza: Asoc. Period. Arag.: 5-18.

Creutz-Kämppi K (2008) The othering of Islam in a European context: polarizing discourses in Swedish-language dailies in Finland. Nordicom Review 29(2): 295-308.

D'Haenens L, Bink S (2007) Islam in the Dutch press: With special attention to the Algemeen Dagblad. Media Culture and Society 29(1): 135-149. 
De Bellaigue C (2018) The New Europeans. New York Review of Books, June 7. Retrieved from https://bit.ly/2mQBkzF. [Accessed 18 September 2019].

De Vreese C, Boomgaarden H, Semetko H (2011) (In)direct framing effects: the effects of news media framing on public support for Turkish membership in the European Union. Communication Research 38(2): 179-205.

Dennison J, Dražanová L (2018) Public Attitudes on Migration: Rethinking how People Perceive Migration. Florence: ICMPD.

Desrues T, Pérez-Yruela M (2008) Percepciones y Actitudes Hacia el Islam y los Musulmanes en España: Avance de Resultados. Madrid: OBERAXE.

Durán R (2016) Framing discourse during the Lampedusa crisis: Victims and intruders in the Spanish press. In Ó Luengo (ed) Political communication in times of crisis, 145158. Berlin: Logos Verlag.

Entman R (1993) Framing: Toward clarification of a fractured paradigm. Journal of Communication 43(4): 51-58.

Entman R (2007) Framing bias: Media in the distribution of power. Journal of Communication 57(1): 163-173.

Eyssel J, Geschke D, Frindte W (2015) Is seeing believing? The relationship between TV consumption and Islamophobia in German majority society. J. Med. Psych. 27(4): 190-202.

Felicetti A, Gattinara P (2018) Toward an assessment of marginality in democratic systems: The Charlie Hebdo debate in the United Kingdom. The British Journal of Politics and International Relations 20(2): 497-517.

Fernández-Suárez B (2016) La imagen de las mujeres inmigrantes en España: la construcción de la alteridad victimizada en los discursos políticos y mediáticos a través del debate sobre el uso de la burka. Rev. Internac. Comunic. Desarr. 1(3): $107-123$.

Givens T, Luedtke A (2005) European immigration policies in comparative perspective: Issue salience, partisanship and immigrant rights. Comparative European Politics 3(1): 1-22.

Greenberg D, Miazhevich G (2012) Assimilationism vs. multiculturalism: U.S. identity and media representations of British Muslims over a 12-year span. Communication, Cultulture \& Critique 5(1): 75-98.

Hafez F (2010) Islamophober Populismus: Moschee- und Minarettbauverbote Österreichischer Parliamentsparteien. Wiesbaden: VS Verlag.

Hafez F (2017) Debating the 2015 Islam law in Austrian Parliament: Between legal recognition and Islamophobic populism. Discourse \&Society 28(4): 392-412.

Humanes ML (2014) Exposición selectiva y partidismo de las audiencias en España. El consumo de información política durante las campañas electorales de 2008 y 2011. Palabra Clave 17(3): 773-802.

Ibrahim D (2010) The framing of Islam on network news following the September $11^{\text {th }}$ attacks". International Communication Gazette 72(1): 111-125.

Imhoff R, Recker J (2012) Differentiating Islamophobia: Introducing a new scale to measure islamoprejudice and secular Islam critique. Political Psychology 33(6): 811824.

Kaufmann E, Goodwin M (2018) The diversity wave: A meta-analysis of the native-born white response to ethnic diversity. Social Science Research 76: 120-131.

Kaya A (2017) Populismo e inmigración en la UE. In J Arango, R Mahía, D Moya, E Sánchez-Montijano (eds) Anuario de la Inmigración 2017, 52-79. Barcelona: CIDOB. 
Keskinen S (2014) Re-constructing the peaceful nation: negotiating meanings of whiteness, immigration and Islam after a shopping mall shooting. Social Identities 20(6): 471-485.

Kunst JR, Tajamala H, Sam DL, Ulleberg P (2012) Coping with Islamophobia: The effects of religious stigma on Muslim minorities' identity formation. International Journal of Intercultural Relations 36(4): 518-532.

McElwee S, McDaniel J (2015) Do racists like Fox News, or does Fox make people racist? FAIR, 22 December. Retrieved from https://fair.org/home/do-racists-like-foxnews-or-does-fox-make-people-racist. [Accessed 18 September 2019].

Martín G, Hernández J, and López MÁ (1997) La Imagen de la Mujer Musulmana en los Medios de Comunicación Españoles. Madrid: Instit. Univ. Estud. Mujer.

Mijares L, Lems J (2018) Luchando contra la subalternidad: las reivindicaciones de la población musulmana en Madrid. Revista de Estudios Internacionales Mediterráneos 24: 109-128.

Nacos B, Torres-Reyna Ó (2007) Fueling our Fears: Stereotyping, Media Coverage, and Public Opinion of Muslim Americans. New York: Rowman \& Littlefield Publishers.

Nemo P (2005) What is the West? Pittsburgh: Duquesne University Press.

Nickels H (2007) Framing asylum discourse in Luxembourg. Journal of Refugee Studies 20(1): 37-59.

Pew Research Center (2018) Eastern and Western Europeans differ on importance of religion, views of minorities, and key social issues. October 29. Retrieved from https://pewrsr.ch/2ow2egC. [Accessed 18 September 2019].

Revenga M, El Mouden A (2010) The politics of integration in Spain. World Congress for Middle Eastern Studies. Barcelona, July, 19-24.

Richardson R (1997) Islamophobia: A Challenge for us all. Report of the Runnymede Trust Commission on British Muslims and Islamophobia. London: Runnymede Trust.

Roggeband C, Vliegenthart R (2007) Divergent framing: The public debate on migration in the Dutch parliament and media, 1995-2004. West European Politics 30(3): 524548.

Ruigrok N, Van Atteveldt W (2007) Global angling with a local angle: How U.S., British, and Dutch newspapers frame global and local terrorist attacks. Harvard International Journal of Press/Politic 12(1): 68-90.

Saeed A (2007) Media, racism and Islamophobia: The representation of Islam and Muslims in the media”. Sociology Compass 1(2): 443-462.

Said E (1978) Orientalism. New York: Pantheon Books.

Said E (1981) Covering Islam. New York: Vintage.

Saleem M, Prot S, Anderson CA, Lemieux AF (2015) Exposure to Muslims in media and support for public policies harming Muslims. Communication Research 44(6): 841869.

Scalvini M (2016) A crisis of religious diversity: Debating integration in post-immigration Europe. Discourse \& Communication 10(6): 614-634.

Scheufele D, Iyengar S (2011) The State of Framing Research: A Call for New Directions. Political Communication Lab Research Papers (Stanford University).

Scheufele D, Tewksbury D (2007) Framing, agenda setting and priming: The evolution of three media effects models. Journal of Communication 57(1): 9-20.

Semetko H, Valkenburg P (2000) Framing European politics: A content analysis of press and television news. Journal of Communication 50(2): 93-109.

UCIDE (2012) Estudio Demográfico de la Población Musulmana. Madrid: Observatorio Andalusí. Retrieved from http://ucide.org. [Accessed 18 September 2019]. 
UCIDE (2018) Estudio Demográfico de la Población Musulmana. Madrid: Observatorio Andalusí. Retrieved from http://ucide.org. [Accessed 18 September 2019].

Uitermark J, Gielen AJ (2010) Islam in the spotlight: the mediatisation of politics in an Amsterdam neighbourhood. Urban Studies 47(6): 1325-1342.

Van Dijk T (2004) Text and context of parliamentary debates. In P Bayley (ed) CrossCultural Perspectives on Parliamentary Discourse, 339-372. Amsterdam: John Benjamins.

Zurbano B, Ortega A, Tarín A (2017) Violencias contra las mujeres en contextos islámicos. Representación y discurso de la prensa de referencia de España. Estudios sobre el Mensaje Periodístico 23(2): 1023-1043. 